\title{
A quantitative trait variant in Gabra2 underlies increased methamphetamine stimulant sensitivity
}

Lisa R. Goldberg ${ }^{1,2}$, Emily J. Yao ${ }^{1}$, Julia C. Kelliher ${ }^{1}$, Eric R. Reed ${ }^{3}$, Jiayi Wu Cox ${ }^{4}$, Cory Parks ${ }^{5}$, Stacey L. Kirkpatrick $^{1}$, Jacob A. Beierle ${ }^{1,2}$, Melanie M. Chen ${ }^{1}$, William E. Johnson ${ }^{6}$, Gregg E. Homanics ${ }^{7}$, Robert W. Williams $^{8}$, Camron D. Bryant ${ }^{1 *}$, Megan K. Mulligan ${ }^{8 *}$

1. Laboratory of Addiction Genetics, Department of Pharmacology and Experimental Therapeutics and Psychiatry, Boston, MA USA

2. NIGMS T32 Ph.D. Training Program in Biomolecular Pharmacology, Boston University School of Medicine, Boston, MA USA

3. Ph.D. Program in Bioinformatics, Boston University, Boston, MA USA

4. Program in Biomedical Sciences, Graduate Program in Genetics and Genomics, Boston University School of Medicine, Boston, MA USA

5. Department of Agricultural, Biology, and Health Sciences, Cameron University, Lawton, OK USA

6. Department of Medicine, Computational Medicine, Boston University School of Medicine

7. Departments of Anesthesiology, Neurobiology, and Pharmacology and Chemical Biology, University of Pittsburgh, Pittsburgh, PA USA

8. Department of Genetics, Genomics and Informatics, University of Tennessee Health Science Center, Memphis, TN USA

${ }^{*}$ co-senior authors

*Camron D. Bryant, Ph.D.

Laboratory of Addiction Genetics

Department of Pharmacology and Experimental Therapeutics and Psychiatry

Boston University School of Medicine

72 E. Concord St.

L-606C

Boston, MA 02118 USA

E: camron@bu.edu

$P:$ (617) 358-9581

\section{*Megan K. Mulligan, Ph.D.}

Department of Genetics, Genomics and Informatics

409 Translational Research Building

University of Tennessee Health Science Center

\section{South Manassas}

Memphis, TN USA

E:mmulliga@uthsc.edu

P: (901) 448-3548 


\section{ABSTRACT}

Psychostimulant (methamphetamine, cocaine) use disorders have a genetic component that remains mostly unknown. Here, we conducted genome-wide quantitative trait locus (QTL) analysis of methamphetamine stimulant sensitivity. To facilitate gene identification, we employed a Reduced Complexity Cross between closely related C57BL/6 mouse substrains and examined maximum speed and distance traveled over 30 min following methamphetamine (2 $\mathrm{mg} / \mathrm{kg}$, i.p.). For maximum methamphetamine-induced speed following the second and third administration, we identified a single genome-wide significant QTL on chromosome 11 that peaked near the Cyfip2 locus [LOD = 3.5, 4.2; peak = $21 \mathrm{cM}(36 \mathrm{Mb})$ ]. For methamphetamine-induced distance traveled, we identified a single genome-wide significant QTL on chromosome 5 that peaked near a functional intronic indel in Gabra2 that codes for the alpha-2 subunit of the GABA-A receptor [LOD = 5.2; peak = $35 \mathrm{cM}$ (67 Mb)]. Striatal cis-expression QTL mapping corroborated Gabra2 as a functional candidate gene underlying methamphetamine-induced distance traveled. CRISPR/Cas9-mediated correction of the mutant intronic deletion on the C57BL/6J background to the wild-type C57BL/6NJ allele was sufficient to reduce methamphetamine-induced locomotor activity toward the wild-type C57BL/6NJ-like level, thus validating the quantitative trait variant (QTV). These studies demonstrate the power and efficiency of Reduced Complexity Crosses in identifying causal genes and variants underlying complex traits. Functionally restoring Gabra2 expression decreased methamphetamine stimulant sensitivity and supports preclinical and human genetic studies implicating the GABA-A receptor in psychostimulant addiction-relevant traits. Importantly, our findings have major implications for investigators studying psychostimulants in the C57BL/6J strain - the gold standard strain in biomedical research.

KEY WORDS: cocaine; stimulant disorders; psychostimulant; addiction; amphetamine; methylphenidate; eQTL; quantitative trait gene; quantitative trait nucleotide 
bioRxiv preprint doi: https://doi.org/10.1101/2021.06.29.450337; this version posted June 30, 2021. The copyright holder for this preprint

(which was not certified by peer review) is the author/funder, who has granted bioRxiv a license to display the preprint in perpetuity. It is made available under aCC-BY-NC-ND 4.0 International license.

\section{INTRODUCTION}

Psychostimulant (methamphetamine, cocaine) use disorders (PUDs) are a serious public health concern. Until the COVID-19 pandemic emerged, the opioid epidemic crisis had begun to plateau. Meanwhile, PUDs have quietly made a resurgence, with increased use and deaths (Cano et al. 2020; Maxwell 2020). Yet, despite an estimated 40-50\% heritability for PUDs (Goldman et al. 2005; Ho et al. 2010; Ducci \& Goldman 2012), genome-wide association studies have identified few loci (Jensen 2016). In one study, a significant GWAS hit for cocaine dependence mapped to FAM53B (Gelernter et al. 2014; Jensen 2016). Notably, an unbiased, quantitative trait locus (QTL) approach in mice identified a trans-expression QTL regulating Fam53b expression that was genetically correlated with variance in cocaine intravenous self-administration (IVSA) in BXD-RI mice, exemplifying cross-species bidirectional translation with discovery genetics in rodents.

Reduced Complexity Crosses exploit the extreme, near-isogenic nature of closely related inbred substrains to rapidly map, pinpoint, and validate quantitative trait loci (QTLs) containing causal quantitative trait genes (QTGs), and quantitative trait variants (QTVs) underlying complex trait variation (Bryant et al. 2018, 2020), including gene expression and behavior (Kumar et al. 2013; Kirkpatrick et al. 2017; Bryant et al. 2019; Mulligan et al. 2019). Of relevance to the present study, Kumar and colleagues used a mouse Reduced Complexity Cross between C57BL/6 substrains to map a missense variant in Cyfip2 with sensitivity to cocaineinduced velocity and extended these findings to methamphetamine (Kumar et al. 2013). We previously used a similar Reduced Complexity Cross to map and validate Cyfip2 in binge-like eating (Kirkpatrick et al. 2017). Also of relevance to the present study, we exploited the reduced complexity of C57BL/6 substrains to identify a functional noncoding single nucleotide deletion in Gabra2 (alpha-2 subunit of the GABA-A receptor) that induced a loss-of-function decrease in transcript and protein expression (Mulligan et al. 2019). Correction of this mutation via CRISPR/Cas9 gene editing restored Gabra2 expression at both the transcript and protein levels (Mulligan et al. 2019). DBA/2 mouse substrains combined with historical BXD-RI substrains have also been exploited to identify a functional missense variant in Taar1 (trace amine-associated receptor 1) underlying differences in the aversive properties of methamphetamine self-administration, body temperature (Harkness et al. 2015) and toxicity (Shi et al. 2016; Miner et al. 2017; Reed et al. 2017).

Administration of addictive drugs such as opioids and psychostimulants increases dopamine release in forebrain regions, including the dorsal striatum and nucleus accumbens, which contributes to the locomotor stimulant and rewarding properties of drugs of abuse (Adinoff, 2004; Di Chiara and Imperato, 1988). Psychostimulant-induced locomotor activity is a rapid, high-throughput heritable trait that is amenable to QTL mapping in multiple genetic populations (Phillips et al. 2008; Bryant et al. 2012a; Parker et al. 2016; Gonzales et al. 2018) and has a shared genetic basis with other addiction-relevant behavioral traits. As two examples, we mapped and validated genetic factors influencing psychostimulant and opioid-induced locomotor activity, including Csnk1e (Bryant et al. 2012c) and Hnrnph1 (Yazdani et al. 2015). Subsequently, we and others have extended the role of these two genes to other complex behavioral models for addiction, including reward as measured via conditioned place preference (Goldberg et al. 2017; Ruan et al. 2020a) and reinforcement as measured via intravenous and oral self-administration (Wager et al. 2014; Ruan et al. 2020a). 
bioRxiv preprint doi: https://doi.org/10.1101/2021.06.29.450337; this version posted June 30, 2021. The copyright holder for this preprint

C57BL/6J (B6J) and C57BL/6NJ (B6NJ) are two substrains of C57BL/6, the most commonly used mouse strain in biomedical research, and are $99.9 \%$ genetically similar, yet exhibit significant differences in several addiction-associated traits (Bryant et al. 2008), including ethanol consumption (Mulligan et al. 2008; Jimenez Chavez et al. 2021), nicotine behaviors (Akinola et al. 2019), and psychostimulant behaviors (Bryant et al. 2008; Kumar et al. 2013). Although phenotypic differences between B6 substrains can be quite large, genotypic diversity is extremely small, with only an estimated 10,000 to 20,000 variants (SNPs plus indels) distinguishing the two strains (Keane et al. 2011; Yalcin et al. 2011; Simon et al. 2013).

In the present study, we used a Reduced Complexity Cross between C57BL/6 substrains to map the genetic basis of sensitivity to the locomotor stimulant properties of methamphetamine, including maximum speed and distance traveled. Following the identification of two historical loci, including one locus for sensitized methamphetamine-induced maximum speed near the Cyfip2 missense mutation that was previously identified for acute and sensitized cocaine velocity (Kumar et al. 2013) and a second locus near the functional intronic variant in Gabra2 (Mulligan et al. 2019), we used a CRISPR/Cas9 gene-edited knockin mouse model with the corrected Gabra2 mutation to validate this functional indel as necessary for enhanced acute stimulant sensitivity that is exhibited in the parental C57BL/6J substrain (Kumar et al. 2013).

\section{MATERIALS AND METHODS}

\section{C57BL/6J (B6J), C57BL/6NJ (B6NJ), and a B6J x B6NJ-F2 Reduced Complexity Cross (Bryant Lab, BUSM)}

All experiments involving mice were approved by the Boston University and University of Tennessee Health Science Center Institutional Animal Use and Care Committees and were conducted in accordance with the AAALAC Guide for the Use and Care of Laboratory Animals (National Research Council (US) Committee for the Update of the Guide for the Care and Use of Laboratory Animals 2011). Mice were housed in an AAALAC-accredited temperature- and climate-controlled facilities on a $12 \mathrm{~h}$ light/dark cycle (lights on at 0630 h). Mice were housed in same-sex groups of two to five mice per cage with standard laboratory chow and water available ad libitum except during testing. Mice were 50-100 days old on the first day of training. All behavioral testing was performed during the light phase of the $12 \mathrm{~h} \mathrm{light/dark}$ cycle (0800 $\mathrm{h}$ to $1300 \mathrm{~h}$ ).

C57BL/6J (B6J; $n=31)$ and C57BL/NJ (B6NJ; $n=32)$ mice were purchased from The Jackson Laboratory (Bar Harbor, ME USA) at 7 weeks of age and were habituated in the vivarium one week prior to experimental testing that occurred next door. All behavioral testing was performed during the light phase of the $12 \mathrm{~h}$ light/dark cycle (0800 h to $1300 \mathrm{~h})$. For QTL mapping, a unidirectional cross was conducted whereby B6J females were crossed to $\mathrm{B} 6 \mathrm{NJ}$ males to generate $\mathrm{B} 6 \mathrm{~J} \times \mathrm{B} 6 \mathrm{NJ}-\mathrm{F}_{1}$ mice and $\mathrm{B} 6 \mathrm{~J} \times \mathrm{B} 6 \mathrm{NJ} \mathrm{F}_{1}$ offspring were intercrossed to generate $\mathrm{B} 6 \mathrm{~J} \times \mathrm{B} 6 \mathrm{NJ} \mathrm{F}_{2}$ mice. All mice within a cage were assigned the same treatment.

All mice comprising the parental substrains and F2 offspring that were behaviorally tested had a prior, identical history of naloxone-induced conditioned place aversion as described in our original publication (Kirkpatrick \& Bryant 2015). Briefly, following initial assessment of preference for the drug-paired side, $24 \mathrm{~h}$ later, mice received two alternating injections of naloxone hydrochloride $(4 \mathrm{mg} / \mathrm{kg}$, i.p.) and two alternating injections of saline (i.p.), separated by $48 \mathrm{~h}$. Seventy-two hours and 96 hours after the second saline trial, mice 
were re-assessed for drug-free and state-dependent conditioned place aversion for the naloxone-paired side, respectively. Thus, all mice received a total of three injections of $4 \mathrm{mg} / \mathrm{kg}$ naloxone over 9 days. One week following recovery from the test for naloxone-induced conditioned place aversion, mice were tested for methamphetamine stimulant sensitivity as described below.

\section{Gabra2 knockin mice}

Gene-edited knockin mice were generated by inserting the corrected Gabra2 intronic nucleotide on the mutant C57BL/6J background via CRISPR/Cas9 gene editing as previously described (Mulligan et al. 2019). Briefly, a sgRNA was designed that targeted Gabra2 at the intron/exon junction near chromosome 5 at 71,014,638 Mb (mm10). A T7 promoter containing the sgRNA template was used to produce sgRNA and Cas9 mRNA that was then purified, ethanol precipitated, and re-suspended in DEPC-treated water. A 121 nucleotide single stranded DNA repair template oligo with the $T$ insertion in the intron of Gabra2 along with sgRNA, and Cas9 mRNA were co-injected into the cytoplasm of B6J one-cell embryos. Offspring of injected embryos were screened for the insertion via PCR amplification of the knockin site. PCR products containing the amplicon were sequenced directly or subcloned into pCR2.1-TOPO (Invitrogen) and sequenced. The male founder (F0) was crossed to female B6J mice to generate F1 progeny. F1 mice were crossed to generate F2 mice. The colony is maintained through heterozygous breeding and all behavioral phenotyping was performed in generations F2 and higher. Potential off-targets were screened using CRISPOR (Haeussler et al. 2016; Concordet \& Haeussler 2018) as previously described (Mulligan et al. 2019) and no off-target modifications were detected in the top 15 predicted off-target sites.

\section{Drugs}

Methamphetamine hydrochloride (MA) (Sigma, St. Louis, MO USA) was dissolved in sterilized, physiological saline (0.9\%) prior to injection (10 ml/kg, i.p.). The dose of MA $(2 \mathrm{mg} / \mathrm{kg}$ ) was chosen based on our prior success in mapping QTLs with this dose (Bryant et al. 2012c, 2012b; Yazdani et al. 2015; Ruan et al. 2020b) and based on a previous study that identified C57BL/6 substrain differences in MA-induced locomotor activity (Kumar et al. 2013).

\section{Methamphetamine-induced maximum speed and distance traveled in B6J, B6NJ, and B6J x B6NJ-F2 mice (Bryant Lab, BUSM)}

The plexiglas apparatus consisted of an open field $(40 \mathrm{~cm}$ length $\times 20 \mathrm{~cm}$ width $\times 45 \mathrm{~cm}$ tall; Lafayette Instruments, Lafayette, IN, USA) surrounded by a sound-attenuating chamber (MedAssociates, St. Albans, VT, USA). Behaviors were recorded using a security camera system (Swann Communications, Melbourne, Australia) and then video tracked (Anymaze, Stoelting, Wood Dale, IL, USA). We employed a five-day locomotor protocol (Ruan et al. 2020b), which is an extended version of the three-day protocol comprising the acute methamphetamine response (Yazdani et al., 2015). On Days (D)1 and 2, mice were injected with SAL (10 ml/kg, i.p.). On D3, D4, and D5 mice were injected with methamphetamine (2 mg/kg, $10 \mathrm{ml} / \mathrm{kg}$, i.p.). Following i.p. injection, mice were immediately placed into the open field and video recorded over 30 min. 
Locomotor phenotypes, including total distance traveled and maximum speed while mobile, were calculated with AnyMaze.

Data were analyzed using repeated measures ANOVA with Strain and Sex as factors and Day as a categorical repeated measure. Time course analysis for a given day was analyzed in a similar manner but with Time (six, 5-min bins) as the repeated measure. Post-hoc analysis was conducted using the family-wide error variance with simple contrasts and Tukey's honestly significant difference to correct for multiple comparisons.

\section{Methamphetamine-induced distance traveled in Gabra2 knockin (KI) mice (Mulligan Lab, UTHSC)}

Validation for the role of the Gabra2 functional intronic single nucleotide deletion (see below) in methamphetamine-induced distance traveled was conducted in the Mulligan Lab at UTHSC. Procedures were similar, though not identical. Here, a larger open field arena $(40 \mathrm{~cm} \times 40 \mathrm{~cm} \times 40 \mathrm{~cm}$ ) was employed and there were no sound attenuating chambers. The larger arena size (1.5-fold larger than the arena used in the Bryant Lab) likely accounts for the overall higher level of locomotor activity in this study compared to the parental strain and F2 studies. Similar to the Bryant Lab, behavior was also recorded with a security camera system and locomotor phenotypes were also calculated in AnyMaze.

\section{DNA collection and genotyping in F2 mice}

DNA was extracted from spleens of F2 mice and prepared for genotyping using a standard salting out protocol. Ninety SNP markers spaced approximately $30 \mathrm{Mb}$ (approximately $15 \mathrm{cM}$ ) apart were genotyped using a custom-designed 96 x 96 Fluidigm SNPtype array (South San Francisco, CA USA) (Kirkpatrick et al. 2017; Bryant et al. 2019). SNPs were called using the Fluidigm SNP Genotyping Analysis Software and SNPtype normalization with the default threshold.

\section{QTL analysis in B6J x B6NJ-F2 mice}

QTL analysis was performed in $\mathrm{F}_{2}$ mice using the $\mathrm{R}$ package $\mathrm{R} / \mathrm{q}$ tl as previously described (Broman et al. 2003; Bryant et al. 2009; Kirkpatrick et al. 2017). Quality checking of genotypes and QTL analysis were

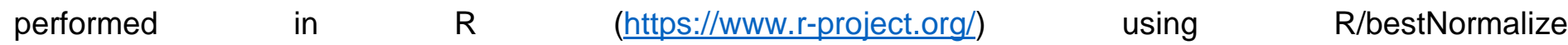
(https://github.com/petersonR/bestNormalize) and R/qtl (Broman et al. 2003). Phenotypes were assessed for normality using the Shapiro-Wilk Test. Because some of the data residuals deviated significantly from normality, we used the orderNorm function to perform Ordered Quantile normalization (Peterson \& Cavanaugh 2019) on all phenotypes. QTL analysis was performed using the "scanone" function and Haley-Knott (HK) regression. Permutation analysis (perm $=1000$ ) was used to compute genome-wide suggestive $(p<0.63)$ and significance thresholds for log of the odds (LOD) scores $(p<0.05)$. Sex was included as an additive covariate in the QTL model. Peak marker positions were converted from sex-averaged cM to Mb using the JAX Mouse Map Converter (http://cgd.jax.org/mousemapconverter). Percent phenotypic variance explained by each QTL was calculated using the "fitqtl" function. 
bioRxiv preprint doi: https://doi.org/10.1101/2021.06.29.450337; this version posted June 30, 2021. The copyright holder for this preprint

Power analysis of Day 5 maximum speed and Day 3 distance traveled using the data from 184 F2 mice was conducted using the R package QTLdesign (Sen et al. 2007). For each phenotype, we generated plots showing power versus \% variance explained for an additively inherited QTL.

\section{RNA-seq for expression QTL (eQTL) analysis}

Striatum was chosen for eQTL anlaysis for historical reasons and because this brain region is a major local site of drug action where methamphetamine binds to the dopamine transporter (and other monoamine transporters) and vesicular monoamine transporters to cause reverse transport of dopamine into the synapse, thus inducing stimulant, rewarding, and reinforcing effects (Chiu \& Schenk 2012). Furthermore, Gabra2containing GABA-A receptors are concentrated in the striatum (Morris et al. 2008) and are a dominant receptor type (Schwarzer et al. 2001). Thus, the striatum is a highly relevant brain tissue to ascertain the effects of Gabra2 genetic variation on the transcriptome as they relate to methamphetamine-induced locomotor stimulation.

Striatum punches were collected as described (Yazdani et al. 2015) for RNA-seq from 23 F2 mice. Details on the prior experimental history of these mice are published (Bryant et al. 2019). Mice were previously trained and tested for place conditioning to oxycodone hydrochloride $(1.25 \mathrm{mg} / \mathrm{kg}$, i.p.; a total of 3 injections over 9 days). Six days later, these mice underwent an additional 4 daily injections of oxycodone (20 mg/kg, i.p.) before being tested for antinociception on the hot plate and then the following week, an additional 4 daily injections of the same dose of oxycodone prior to testing for affective withdrawal on the elevated plus maze 16 $\mathrm{h}$ later. Brains were harvested $24 \mathrm{~h}$ after behavioral assessment of oxycodone withdrawal (approximately $40 \mathrm{~h}$ after the final injection of oxycodone).

Brains were rapidly removed and sectioned with a brain matrix to obtain a $3 \mathrm{~mm}$ thick section where a 2 $\mathrm{mm}$ diameter punch of the striatum was collected. Left and right striatum punches were pooled and immediately placed in RNAlater (Life Technologies, Grand Island, NY, USA) and stored for $48 \mathrm{~h}$ at $4^{\circ} \mathrm{C}$ prior to storage in a $-80^{\circ} \mathrm{C}$ freezer. Total RNA was extracted using the RNeasy kit (Qiagen, Valencia, CA, USA) as described (Yazdani et al. 2015). RNA was shipped to the University of Chicago Genomics Core Facility for cDNA library preparation using the Illumina TruSeq (oligo-dT; 100 bp paired-end reads). Libraries were prepared according to Illumina's detailed instructions accompanying the TruSeq ${ }^{\circledR}$ Stranded mRNA LT Kit (Part\# RS-122-2101). The purified cDNA was captured on an Illumina flow cell for cluster generation and sample libraries were sequenced at 23 samples per lane over 5 lanes (technical replicates) according to the manufacturer's protocols on the Illumina HiSeq 4000 machine, yielding an average of 69.4 million paired-end reads per sample. FASTQ files were quality checked via FASTQC and possessed Phred quality scores $>30$ (i.e. less than $0.1 \%$ sequencing error). This dataset is publicly available on Gene Expression Omnibus (GEO \#119719).

\section{Cis- and trans-expression QTL (eQTL) analysis}

Details on eQTL mapping are published (Bryant et al. 2019). We aligned FastQ files to the reference genome (mm38) via TopHat (Trapnell et al. 2012) using the mm38 build and Ensembl Sequence and genome 
annotation. We used featureCounts to count and align reads. For cis-eQTL analysis, we used the same marker panel that we used in behavioral QTL analysis. We removed lowly expressed exons that did not possess at least 10 reads total across all 115 count files. Because of the low resolution of QTL mapping in an F2 cross, we liberally defined a gene with a cis-eQTL as any gene possessing a genome-wide significant association between expression and a polymorphic marker that was within $70 \mathrm{Mb}$ of a SNP (the largest distance between any two SNPs from the 90-SNP panel). Analysis was conducted using limma with default TMM normalization and VOOM transformation (Law et al. 2014; Ritchie et al. 2015). A linear model was employed whereby sample replicates were treated as a random effects repeated measure. The duplicateCorrelation() function was used to estimate within-sample correlation, which was then included in the ImFit() function. An ANOVA test was conducted for gene expression that included Sex as a covariate and Genotype as a fixed effect. Genelevel tests were conducted using the likelihood Ratio test. A false discovery rate of $5 \%$ was employed as the cut-off for statistical significance (Benjamini \& Hochberg 1995).

\section{Enrichment analysis}

Enrichment analysis of genes whose transcripts correlated with Gabra2 transcript levels ( $r \leq-0.5$ or $r \geq$ 0.5; $p \leq 0.015$ ) was conducted using the online tool Enrichr (Chen et al. 2013; Kuleshov et al. 2016) where we report GO terms for molecular, cellular, and biological function.

\section{RESULTS}

B6J mice show an increase in methamphetamine-induced maximum speed and locomotor activity compared to B6NJ mice

In examining B6 substrain differences in maximum speed, there were no substrain difference in response to saline injections (10 ml/kg, i.p.) on Days 1 and 2 (p's > 0.05). However, in response to methamphetamine (2 mg/kg, i.p.) on Day 3, Day 4, and Day 5, B6J mice showed increased maximum speed relative to $\mathrm{B} 6 \mathrm{NJ}$ mice, regardless of whether the data were collapsed across Sex or analyzed separately in females and males (Fig.1A-C).

In examining B6 substrain differences in distance traveled following saline versus methamphetamine, there were no substrain differences in distance traveled in response to saline on Days 1 and 2 ( $p$ 's $>0.05$ ). However, in response to methamphetamine, B6J mice showed an increase in distance traveled compared to B6NJ mice on Day 3, Day 4, and Day 5, regardless of whether the data were collapsed across Sex or analyzed separately in females and males (Fig.1D-F). These results replicate previous B6 substrain differences in the B6 mice from the $\mathrm{J}$ lineage show increased stimulant sensitivity compared to $\mathrm{B} 6$ mice from the $\mathrm{N}$ lineage (Kumar et al. 2013).

\section{Chromosome 11 QTL near the Cyfip2 missense mutation underlying variation in sensitized} methamphetamine-induced maximum speed $(\mathrm{m} / \mathrm{s})$

Next, we sought to identify the genetic basis of differential methamphetamine-induced stimulant sensitivity in B6 substrains using an F2 Reduced Complexity Cross (Bryant et al. 2018, 2020). We identified a 
genome-wide significant QTL on chromosome 11 underlying maximum speed while mobile that was specific to methamphetamine treatment and emerged after the second and third methamphetamine injection on Day 4 and Day 5 (LOD = 3.5, 4.2; $p=0.039$, 0.009; Fig.2A), thus requiring repeated methamphetamine exposure. The marker nearest the peak [rs48169870; $18 \mathrm{cM}(31 \mathrm{Mb})$ ] was located just proximally to the Cyfip2 missense mutation [rs24064617401; 28 cM (46 Mb); Fig.2B] previously identified for acute and sensitized cocaine velocity (Kumar et al. 2013). Like the previous finding, the B6J allele was associated with increased methamphetamine-induced maximum speed (Fig.2C). Thus, the locus containing the Cyfip2 missense mutation is associated with behavioral sensitivity to multiple psychostimulants.

\section{Chromosome 5 QTL near the Gabra2 intronic deletion underlying variation in acute methamphetamine-} induced locomotor activity (total distance traveled; $\mathbf{m}$ )

We identified two genome-wide significant QTLs on chromosome 5 that influenced locomotor activity (distance, $\mathrm{m}$ ). The first QTL was for Day 2 distance traveled (saline) and was localized more proximally [peakmarker $=22 \mathrm{cM}(41 \mathrm{Mb})$; LOD = 3.8; $\mathrm{p}=0.037$; Fig.3A,B]. The second QTL was located more distally [peak marker $=35 \mathrm{cM}(67 \mathrm{Mb})]$ near the Gabra2 intronic deletion $(71 \mathrm{Mb})$ and was significant in response to the first and second methamphetamine injections on Day 3 and Day 4, respectively (LOD = 5.2, 3.6; $p<0.001,0.034$; Fig.3A,B). The B6J allele was associated with increased methamphetamine-induced distance traveled, as indicated by the effect plot in Fig. 3C. In examining the time course for the chromosome 5 QTL, the $\mathrm{J}$ allele was consistently associated with increased methamphetamine-induced distance traveled across the six, 5-min time bins (Fig.3D). Because we identified both a Sex x Day interaction and a Substrain x Day interaction in distance traveled in the parental substrains, we broke down and analyzed the time course of the effect plot separately in females and males and found that males clearly drove the QTL effect compared to females (Fig.3E,F).

Power analysis of the 184 F2 mice that we phenotyped in this study indicated that we had approximately $80 \%$ power to detect QTLs explaining at least $10 \%$ of the variance in maximum speed and in distance traveled (Supplementary Figure 1).

\section{Striatal cis-eQTL analysis identifies Gabra2 as the top transcript associated with rs29547790; the peak chromosome 5 marker linked to methamphetamine-induced distance traveled}

Given that the likely causal variant underlying maximum speed induced by methamphetamine for the chromosome 11 locus was a missense variant in Cyfip2 (Kumar et al. 2013), we turned our attention to the novel chromosome 5 locus whose peak marker (rs29547790; 70,931,531 bp) is located just proximally to a functional intronic deletion in Gabra2 (71 Mb) (Mulligan et al. 2019) which codes for the alpha-2 subunit of the GABA-A receptor. In a genome-wide cis-eQTL analysis, we examined eQTLs associated with the peak chromosome 5 marker associated with methamphetamine-induced locomotor activity (rs29547790; 70.93 Mb). The top transcript was Gabra2 (chromosome 5, $70.96 \mathrm{Mb}$; $p_{\text {adjusted }}=7.2 \times 10^{-27}$; Table 1). Given this finding and the prior literature implicating Gabra2 in psychostimulant behavioral responses (Stephens et al. 2017), Gabra2 is a top candidate quantitative trait gene underlying the chromosome 5 QTL for methamphetamine-induced 
locomotor activity. A list of 59 trans-eQTLs ( $p<0.0001)$ showing a peak association with rs29547790 is provided in Supplementary Table 2.

\section{Gabra2-correlated transcripts and enrichment analysis}

To gain insight into the neurobiological adaptations associated with differential Gabra2 expression at the genomic level, we examine the correlation of Gabra2 with other transcripts genome-wide. We identified 148 transcripts with an absolute Pearson's $r$ value of 0.5 or greater ( $p \leq 0.015$; Supplementary Table 3 ). We conducted enrichment analysis of this gene list using Enrichr (Chen et al. 2013; Kuleshov et al. 2016) to identify GO molecular, cellular, and biological functions linked to decreased Gabra2 expression. We identified several enrichment terms related to the GABA-A receptor signaling (Table 2) that were mainly driven by other GABA-A receptor subunits that were positively correlated with Gabra2 expression (Gabre, Gabrg3; $r=+0.56$, +0.50; $p \leq 0.015$; Supplementary Table 4). Other nominally, positively correlated GABA-A subunit transcripts included Gabrb1 ( $r=+0.37 ; p=0.08$ ) and Gabrq $(r=+0.36 ; p=0.09)$ (Supplementary Table 4). Additional GABA signaling-relevant transcripts that were correlated include the GPCR kinase coded by Grk5 $(r=+0.51$; $p=0.013)$ (Kanaide et al. 2007) and the amino acid transporters coded by Slc3a2 $(r=-0.51 ; p=0.014)$, and Slc38a5 ( $r=-0.59 ; p=0.003)$ (Cubelos et al. 2005).

\section{CRISPR/Cas9 correction of the functional intronic deletion in Gabra2 reduces methamphetamine- induced distance traveled in B6J mice toward a B6NJ-like level}

Based on co-mapping of a behavioral QTL with a highly robust striatal cis-eQTL for Gabra2 expression and based on the known functional intronic variant within Gabra2 harbored by the B6J substrain that decreases Gabra2 expression (Mulligan et al. 2019), we tested the hypothesis that this single intronic nucleotide deletion in Gabra2 located near a splice acceptor site (71,014,638 bp) in the B6J strain is the quantitative trait variant underlying variance in methamphetamine-induced locomotor activity. Specifically, we predicted that the Gabra2 deletion increases methamphetamine sensitivity in B6J mice and that correction of this deletion via CRISPR-Cas9-mediated insertion of the B6NJ wild-type nucleotide would reduce methamphetamine-induced distance traveled toward a B6NJ-like level. Furthermore, given the more pronounced phenotypic effect of Genotype at the Gabra2 locus in males compared to females (Fig.3E, F), we predicted that genotypic restoration of the wild-type allele would exert a more pronounced decrease in methamphetamine-induced distance traveled in male versus female mice.

Consistent with our predictions, there was no genotypic difference in distance traveled on Day 1 or Day 2 following saline (i.p.) injections. Sex-combined data from C57BL/6J mice homozygous for the Gabra2 mutational correction [reinsertion of the deleted intronic nucleotide; "knockin" (Gabra2 KI); Fig.4A] showed a decrease in methamphetamine-induced distance traveled on all three days of methamphetamine exposure (D3, D4, D5; Fig.4B). Consistent with the QTL results from F2 mice at the chromosome 5 locus, there was no genotypic difference in methamphetamine-induced locomotor activity in females on Day 3 (Fig.4C), while on Day 4 and Day 5, female $\mathrm{KI}$ mice showed a significant decrease in methamphetamine-induced locomotor activity (Fig.4C). On the other hand and again, consistent with the QTL results from F2 mice, male $\mathrm{KI}$ mice 
bioRxiv preprint doi: https://doi.org/10.1101/2021.06.29.450337; this version posted June 30, 2021. The copyright holder for this preprint

showed a significant decrease in methamphetamine-induced distance traveled following the first and second methamphetamine administration on Day 3 and Day 4, with no genotypic difference on Day 5 (Fig.4D).

Based on the QTL that was significant for the first methamphetamine exposure on Day 3 (Fig.3A,B; green traces), we were primarily interested in this phenotype and so we broke down the data for Day 3 into 5min bins like we did with the F2 mice (Fig.3D-F) to more closely examine the sex-combined and sex-stratified datasets. Similar to the F2 results for the chromosome 5 locus, the effect of Genotype on acute methamphetamine-induced locomotor activity was more pronounced in males. For the sex-combined dataset, Gabra2 KI mice showed a significant decrease in methamphetamine-induced locomotor activity from $10 \mathrm{~min}$ to 30 min post-methamphetamine (Fig.5A). For females-only, there was no significant genotypic difference at any of the six time bins (Fig.5B). For males, there was a significant decrease in methamphetamine-induced locomotor activity in $\mathrm{KI}$ males from $15 \mathrm{~min}$ to $30 \mathrm{~min}$ (Fig.5C). Thus, like F2 males with the chromosome 5 QTL, male Gabra2 KI mice account for the sex-combined phenotype of decreased methamphetamine-induced distance traveled in mice with the wild-type (KI) allele compared to the Gabra2 deletion.

\section{DISCUSSION}

We replicated the enhanced psychostimulant sensitivity in B6J compared to $\mathrm{N}$ substrains (Kumar et al. 2013) (Fig.1). We then used a Reduced Complexity Cross between C57BL/6 substrains to identify a QTL near the Cyfip2 missense mutation previously identified for cocaine velocity (Kumar et al. 2013) that influenced methamphetamine-induced maximum speed (Fig.2). Next, we identified a novel QTL near the known functional intronic deletion in Gabra2 (Mulligan et al. 2019) that influenced methamphetamine-induced distance traveled (Fig.3). Cis-eQTL analysis of striatal tissue from F2 mice implicated Gabra2 as a causal quantitative trait gene underlying increased methamphetamine stimulant sensitivity (Table 1). Finally, CRISPR/Cas9 correction of the single nucleotide deletion via CRISPR-Cas9 reversed the enhanced methamphetamine sensitivity toward a C57BL/6NJ-like level (Fig.4), thus recapitulating the QTL effect (Fig.5 vs. Fig.3) and identifying the quantitative trait nucleotide.

Despite the fact that Gabra2 KI mice recapitulated the effect of Sex-dependent effect of Genotype at the chromosome 5 QTL containing the Gabra2 deletion, neither result recapitulated the parental strain phenotype where both female B6J and male B6J mice harboring the Gabra2 deletion showed qualitatively similar increases in methamphetamine-induced distance traveled on Day 3 (Fig.1E,F). This discrepancy is likely explained by the fact that these B6 substrains each harbor their own unique set of variants that contribute to the overall phenotype, including notably, the Cyfip2 missense mutation in C57BL/6N that decreases psychostimulant velocity (Kumar et al. 2013).

To our knowledge, this is the first time that a Gabra2 variant has been identified to influence methamphetamine behavior as previous studies focused primarily on cocaine, e.g., Gabra2 knockouts with deletion of exon 4 (Dixon et al. 2008). Gabra2 encodes the alpha 2 subunit of the gamma-aminobutryic acid A (GABA-A) receptor, a pentameric, ligand-gated ion channel that mediates fast inhibitory neurotransmission via ligand-gated choloride influx and neuronal hyperpolarization (Olsen \& Sieghart 2008). Gabra2-containing GABA-A receptors are expressed in several limbic regions involved in motivation and reward, including 
bioRxiv preprint doi: https://doi.org/10.1101/2021.06.29.450337; this version posted June 30, 2021. The copyright holder for this preprint (which was not certified by peer review) is the author/funder, who has granted bioRxiv a license to display the preprint in perpetuity. It is made available under aCC-BY-NC-ND 4.0 International license.

notably, the nucleus accumbens (Schwarzer et al. 2001; Morris et al. 2008). Chronic methamphetamine administration leads to an increase in Gabra2 mRNA in several brain regions, including the striatum and ventral tegmental area (Tamaki et al. 2008). Furthermore, GABRA2 variants are associated with variance in psychostimulant behavioral responses and addiction, including cocaine (Dixon et al. 2010; Enoch et al. 2010; Smelson et al. 2012) and methyphenidate (Duka et al., 2015).

Interestingly, in contrast to our observation of enhanced methamphetamine behavior in B6J mice with the Gabra2 intronic indel (corresponding to reduced Gabra2 expression), constitutive Gabra2 knockout mice on a mixed C57BL/6J/129SvEv genetic background showed a decrease in cocaine-induced behaviors, including cocaine-induced reinforcement and locomotor sensitization (Dixon et al. 2010), with no phenotypic difference in cocaine intravenous self-administration or reinstatement of cocaine seeking (Dixon et al. 2014). Discrepancies could potentially be explained by multiple factors. First, the Gabra2 intronic deletion is a different type of mutation compared to deletion of an entire exon (exon 4) in Gabra2 knockouts (Dixon et al. 2008) there is still a clearly detectable level of expression at the mRNA and protein level in multiple brain regions in B6J mice containing the Gabra2 intronic indel (Mulligan et al. 2019). Thus, there could be fewer or different compensatory neuroadaptations in the GABA system (e.g., changes in other GABA-A subunits) in response to the constitutive Gabra2 intronic indel compared to the Gabra2 knockout. Interestingly, our findings are consistent with some of the literature. For example, like the Gabra2 intronic indel, antisense oligodeoxynucleotides against Gabra2 in the striatum adult Sprague-Dawley rats increased sensitivity to cocaine-induced locomotor activity and stereotypy (Peris et al. 1998). Second, methamphetamine has a different mechanism of action (reverses transport of monoamines) than cocaine (blocks transport of monoamines) and thus, it is possible that the Gabra2 variants lead to different effects with different psychostimulants (Resnick et al. 1999). In support, the Gabra2 locus was not identified to be linked to cocaine velocity in a reduced complexity cross that segregated this variant (Kumar et al. 2013). To our knowledge, behavioral responses to amphetamines have not been reported in Gabra2 knockouts. Third, because the Gabra2 knockout is on a mixed background containing 129SvEv and C57BL/6J alleles, including the Gabra2 intronic indel, it is possible that phenotypic detection of exon 4 deletion is obscured by segregation of the Gabra2 intronic indel and/or 129SvEv variants.

The impact of reduced Gabra2 levels on neuronal function has yet to be determined. Dixon and colleagues reported a 33\% decrease in miniature inhibitory postsynaptic current (IPSC) and prolonged decay, but no difference in frequency in the nucleus accumbens of Gabra2 knockout mice (Dixon et al. 2010). On the other hand, other groups have reported no change in CA1 pyramidal cell IPSCs following Gabra2 genetic deletion (Panzanelli et al. 2011). Comparison of perisomatic asynchronous IPSCs in CA1 neurons between B6J containing the Gabra2 intronic indel and the corrected B6J KI line at baseline and following treatment with a Gabra2/Gabra3 selective positive allosteric modulator (PAM) revealed a prolonged decay in the corrected $\mathrm{KI}$ line (Hawkins et al. 2021), indicating a restoration of PAM effects on receptor function. Kearney and colleagues found a reduction in Gabra2-containing receptors without a general reduction in overall GABA-A receptors in B6J versus corrected $\mathrm{KI}$ mice (Hawkins et al. 2021). The latter finding implicates a heteromeric receptor composition (containing both Gabra1 and Gabra2) at perisomatic GABAergic synapses and that Gabra2- 
bioRxiv preprint doi: https://doi.org/10.1101/2021.06.29.450337; this version posted June 30, 2021. The copyright holder for this preprint available under aCC-BY-NC-ND 4.0 International license.

containing receptors might play a major role in mediating perisomatic phasic inhibition. These changes were associated with premature death and more severe seizures in B6J mice heterozygous for deletion of the Dravet syndrome candidate gene Scn1a relative to corrected lines heterozygous for the same deletion. However, inhibitory signaling was not profiled in other brain regions. Previous comparisons of GABA-A receptor mRNA expression in cortex, hippocampus, and striatum between B6J and the corrected $\mathrm{KI}$ line found a more profound alteration in subunit expression in the striatum compared to other brain regions (Mulligan et al. 2019). Taken together, these results suggest functional alterations in inhibitory signaling associated with a reduction of Gabra2, although the precise mechanisms and functional impact are likely to vary by cell type and brain region.

In the context of our previous findings (Mulligan et al. 2019), our current set of results support the notion that reduced Gabra2 expression and plausibly, altered pentameric GABA-A receptor function leads to enhanced methamphetamine stimulant sensitivity which is in line with an inverse relationship between GABA-A receptor function (ability to transport chloride) and cocaine-induced locomotor stimulation (Peris 1996). To gain insight into neurobiological adaptations associated with reduced Gabra2 expression, transcript covariance analysis of striatal tissue from F2 mice identified two other subunits that were positively correlated with Gabra2 expression ( $r \geq+0.5, p<0.05$ ), including Gabre and Gabrg3 (Table 3; Supplementary Table 4) and two nominally correlated GABA-A subunit transcripts, including Gabrb1 ( $r=+0.37 ; p=0.083)$ and Gabrq ( $r=$ +0.36; $p=0.089$ ) (Supplementary Table 4). Thus, one hypothesis is that the concomitant decrease in expression in one or more of these GABA-A subunits with Gabra2 leads to decreased assembly and thus a decrease in the number of functional GABA-A receptors. In particular, Gabrg3 and Gabrb1 were highly expressed at a level comparable to Gabra2 (Supplementary Table 4), providing further confidence in these results. In support of Gabra2-Gabrb1 covariance in expression, a GABRA2 risk variant for alcohol dependence leading to reduced expression of GABRA2 positively correlated with expression of GABRB1, GABRG1, and GABRA4 in human iPSCs (Lieberman et al. 2015).

Gabrb1 is coexpressed with Gabra2 in vivo (Olsen \& Sieghart 2008; Stephens et al. 2017). GABRB1 variants have been associated with alcohol dependence and co-morbid substance use disorders (Stephens et al. 2017) and altered fMRI BOLD signal in multiple gyri and the caudate/insula during impulsivity and reward sensitivity tasks (Duka et al. 2017); thus, GABRB1 is hypothesized to regulate excitability of GABA-A receptors in brain regions underlying reward-related behavior and possibly addiction. Concomitant decreases in Gabrb1 and Gabra2 expression were observed in cortex, striatum, and hippocampus of B6J mice relative to the corrected B6J KI line (Mulligan et al. 2019). In striatum, Gabra2 was previously found to assemble with Gabrb2 or Gabrb3 but not Gabrb1 (Hörtnagl et al. 2013), which could indicate additional changes in function of GABA-A receptors that do not contain Gabra2. Other subunits that were positively correlated with Gabra2 expression were expressed at a very low levels, including Gabre $(r=+0.56 ; p=0.0053)$ and Gabrq $(r=+0.25$; $\mathrm{p}=0.089$ ) (Supplementary Table 3 ). Thus, these correlations could be spurious.

Interestingly, in both F2 mice and Gabra2 KI mice, the effect of Gabra2 Genotype on acute methamphetamine-induced distance traveled was more pronounced in males versus females. The recapitulation of the sex-dependent genotypic effect from the QTL phenotype to the KI phenotype was striking 
bioRxiv preprint doi: https://doi.org/10.1101/2021.06.29.450337; this version posted June 30, 2021. The copyright holder for this preprint (which was not certified by peer review) is the author/funder, who has granted bioRxiv a license to display the preprint in perpetuity. It is made available under aCC-BY-NC-ND 4.0 International license.

(Figs.3E,F vs. Fig.5B,C) and further strengthens the support for the Gabra2 indel as the causal, quantitative trait variant (Mulligan et al. 2019). What is the mechanism underlying the larger increase in methamphetamineinduced locomotor activity in males with the B6J Gabra2 intronic deletion? One possibility is that male mutants show a larger reduction in Gabra2 transcript levels. Our present transcriptome dataset is not powered to detect sex differences; however, previous datasets fail to support sex-dependent effects of the B6J Gabra2 indel on Gabra2 expression. We did not identify any previous sex differences in Gabra2 expression between B6 substrains or in B6J relative to the Gabra2-corrected KI line (Mulligan et al. 2019). Furthermore, using a hypothalamic dataset from BXD strains on GeneNetwork that contained both sexes (Chesler et al. 2004; Mulligan et al. 2017), there was no sex difference in Gabra2 expression in BXD-RI strains with or without the B6J-derived Gabra2 intronic deletion as expression levels in female versus male BXD-Ri strains were highly correlated, regardless of Gabra2 mutant genotype status $\left(r=0.91 ; p<1 \times 10^{-16}\right.$; Supplementary Figure 2). Thus, sex differences in the mutational effect of the B6J-derived Gabra2 intronic indel on transcription are unlikely to explain the enhanced effect of the chromosome 5 QTL or the Gabra2 KI allele on methamphetamine sensitivity in males. Alternatively, sex differences in other neurotransmitter or neuromodulatory systems could interact with the Gabra2 Genotype in determining the methamphetamine behavioral response. For example, sex-dependent interactions of endogenous opioid function and alcohol drinking on Gabra2 expression in mice have been reported (Rhinehart et al. 2018).

There are several limitations to this study. First, the parental B6 substrains and the F2 mice used for behavioral QTL analysis all had prior (but equal) exposure to naloxone over the course of 9 days that could have potentially influenced subsequent methamphetamine-induced behaviors as described in the Methods this turned out not to be the case, as we nicely replicated the B6 substrain difference in methamphetamineinduced locomotor activity that was previously identified for methamphetamine-induced locomotor activity (B6J $>$ B6N) (Kumar et al. 2013). Prior naloxone exposure could have enhanced our ability to detect the chromosome 5 QTL but this potential confound was offset by the fact that gene-edited Gabra2 KI mice were completely naïve from any drug or experimental manipulations, yet the results qualitatively recapitulated the effect of the chromosome 5 QTL, despite the fact that the two studies were conducted in entirely different laboratories at different institutions. Another limitation is that the F2 mice from which samples were collected for striatal eQTL analysis had prior exposure to the mu opioid receptor agonist oxycodone as described in the Methods. However, this concern is mitigated by the fact that the eQTL was in the same direction as the prior report of Gabra2 expression differences between B6J and B6N (B6J < B6N) (Mulligan et al. 2019; Mortazavi et al. 2021). Finally, we only conducted eQTL analysis from a single brain tissue, the striatum. However, note that we previously identified reduced Gabra2 expression at both the transcript and protein levels in multiple brain regions, including cortex, hippocampus, and striatum (Mulligan et al. 2019); thus, the functional effects of this variant on Gabra2 expression are ubiquitous across CNS tissues examined.

To summarize, we replicated a historical QTL near the Cyfip2 missense mutation underlying differential sensitivity to psychostimulant-induced maximum speed and identified a novel QTL and quantitative trait variant in Gabra2 that underlies enhanced stimulant sensitivity to methamphetamine. This study further illustrates the efficiency of Reduced Complexity Crosses in systems genetic analysis of complex traits to rapidly identify 
causal genes and nucleotides (Bryant et al. 2018, 2020). Future studies will identify the brain regions, cell types, circuits, and physiological mechanisms underlying the relationship between reduced Gabra2 expression and GABA-A receptor function to enhancement of psychostimulant behaviors.

\section{DECLARATIONS}

\section{CONFLICT OF INTEREST STATEMENT}

The authors declare no conflicts of interest.

\section{CONSENT TO PUBLICATION}

All authors have read and approved of the final version of the manuscript that has been submitted for publication.

\section{FUNDING}

This work was funded by R03DA038287 (C.D.B.), R21DA038738 (C.D.B.), R01DA039168 (C.D.B.), U01DA050243 (C.D.B.), U01AA13499 (M.K.M. and R.W.W.) and U01AA016662 (M.K.M. and R.W.W.)

\section{AUTHORS' CONTRIBUTIONS}

L.R.B., E.J.Y., and J.C.K. conducted a majority of the statistical analyses and data presentation and contributed to the writing of the manuscript. E.R.R and J.W.C. analyzed data. C.P., C.W., M.D., and S.K. generated data. J.A.B. and M.M.C. analyzed data. S.L.K. generated and analyzed data. G.E.H. generated reagents. R.W.W. contributed to writing the manuscript. C.D.B. conceived of the studies, advised in the analysis, and wrote the manuscript. M.K.M. generated and analyzed data and contributed to writing the manuscript.

\section{ACKNOWLEDGMENTS}

We acknowledge the superb technical support of Sufiya Khanam and Christine Watkins (UTHSC).

\section{DATA AVAILABILITY STATEMENT}

All data in its raw and processed forms will be made immediately available upon request. 


\section{REFERENCES}

Akinola, L.S., Mckiver, B., Toma, W., Zhu, A.Z.X., Tyndale, R.F., Kumar, V. \& Damaj, M.I. (2019) C57BL/6 Substrain Differences in Pharmacological Effects after Acute and Repeated Nicotine Administration. Brain Sci 9.

Benjamini, Y. \& Hochberg, Y. (1995) Controlling false discovery rate: A practical and powerful approach to multiple testing. Journal of the Royal Statistical Society 57, 289-300.

Broman, K.W., Wu, H., Sen, S. \& Churchill, G.A. (2003) R/qtl: QTL mapping in experimental crosses. Bioinformatics (Oxford, England) 19, 889-90.

Bryant, C.D., Bagdas, D., Goldberg, L.R., Khalefa, T., Reed, E.R., Kirkpatrick, S.L., Kelliiher, J.C., Chen, M.M., Johnson, W.E., Mulligan, M.K. \& Damaj, M.I. (2019) C57BL/6 substrain differences in inflammatory and neuropathic nociception and genetic mapping of a major quantitative trait locus underlying acute thermal nociception. Mol Pain 1744806918825046.

Bryant, C.D., Ferris, M.T., De Villena,F.P.M., Damaj, M.I., Kumar, V. \& Mulligan, M.K. (2018) Reduced complexity cross design for behavioral genetics. In Gerlai, R.T. (ed), Molecular-Genetic and Statistical Techniques for Behavioral and Neural Research, pp. 165-190.

Bryant, C.D., Kole, L.A., Guido, M.A., Cheng, R. \& Palmer, A.A. (2012a) Methamphetamine-induced conditioned place preference in LG/J and SM/J mouse strains and an F45/F46 advanced intercross line. FrontGenet 3, 126.

Bryant, C.D., Kole, L.A., Guido, M.A., Sokoloff, G. \& Palmer, A.A. (2012b) Congenic dissection of a major QTL for methamphetamine sensitivity implicates epistasis. Genes Brain Behav 11, 623-632.

Bryant, C.D., Parker, C.C., Zhou, L., Olker, C., Chandrasekaran, R.Y., Wager, T.T., Bolivar, V.J., Loudon, A.S., Vitaterna, M.H., Turek, F.W. \& Palmer, A.A. (2012c) Csnk1e is a genetic regulator of sensitivity to psychostimulants and opioids. Neuropsychopharmacology 37, 1026-1035.

Bryant, C.D., Smith, D.J., Kantak, K.M., Nowak, T.S., Williams, R.W., Damaj, M.I., Redei, E.E., Chen, H. \& Mulligan, M.K. (2020) Facilitating Complex Trait Analysis via Reduced Complexity Crosses. Trends Genet 36, 549-562.

Bryant, C.D., Zhang, N.N., Sokoloff, G., Fanselow, M.S., Ennes, H.S., Palmer, A.A. \& McRoberts, J.A. (2008) Behavioral differences among C57BL/6 substrains: implications for transgenic and knockout studies. JNeurogenet 22, 315-331.

Cano, M., Oh, S., Salas-Wright, C.P. \& Vaughn, M.G. (2020) Cocaine use and overdose mortality in the United States: Evidence from two national data sources, 2002-2018. Drug Alcohol Depend 214, 108148.

Chen, E.Y., Tan, C.M., Kou, Y., Duan, Q., Wang, Z., Meirelles, G.V., Clark, N.R. \& Ma'ayan, A. (2013) Enrichr: interactive and collaborative HTML5 gene list enrichment analysis tool. BMC Bioinformatics 14, 1282105-14-128.

Chesler, E.J., Lu, L., Wang, J., Williams, R.W. \& Manly, K.F. (2004) WebQTL: rapid exploratory analysis of gene expression and genetic networks for brain and behavior. Nature neuroscience 7, 485-6.

Chiu, V.M. \& Schenk, J.O. (2012) Mechanism of action of methamphetamine within the catecholamine and serotonin areas of the central nervous system. CurrDrug Abuse Rev 5, 227-242.

Concordet, J.-P. \& Haeussler, M. (2018) CRISPOR: intuitive guide selection for CRISPR/Cas9 genome editing experiments and screens. Nucleic Acids Res 46, W242-W245.

Cubelos, B., González-González, I.M., Giménez, C. \& Zafra, F. (2005) Amino acid transporter SNAT5 localizes to glial cells in the rat brain. Glia 49, 230-244. 
bioRxiv preprint doi: https://doi.org/10.1101/2021.06.29.450337; this version posted June 30, 2021. The copyright holder for this preprint (which was not certified by peer review) is the author/funder, who has granted bioRxiv a license to display the preprint in perpetuity. It is made available under aCC-BY-NC-ND 4.0 International license.

Dixon, C.I., Halbout, B., King, S.L. \& Stephens, D.N. (2014) Deletion of the GABAA a2-subunit does not alter self administration of cocaine or reinstatement of cocaine seeking. Psychopharmacology (Berl) 231, 2695-2703.

Dixon, C.I., Morris, H.V., Breen, G., Desrivieres, S., Jugurnauth, S., Steiner, R.C., Vallada, H., Guindalini, C., Laranjeira, R., Messas, G., Rosahl, T.W., Atack, J.R., Peden, D.R., Belelli, D., Lambert, J.J., King, S.L., Schumann, G. \& Stephens, D.N. (2010) Cocaine effects on mouse incentive-learning and human addiction are linked to alpha2 subunit-containing GABAA receptors. Proc Natl Acad Sci U S A 107, 2289-2294.

Dixon, C.I., Rosahl, T.W. \& Stephens, D.N. (2008) Targeted deletion of the GABRA2 gene encoding alpha2subunits of $\mathrm{GABA}(\mathrm{A})$ receptors facilitates performance of a conditioned emotional response, and abolishes anxiolytic effects of benzodiazepines and barbiturates. Pharmacol Biochem Behav 90, 1-8.

Ducci, F. \& Goldman, D. (2012) The genetic basis of addictive disorders. PsychiatrClinNorth Am 35, 495-519.

Duka, T., Nikolaou, K., King, S.L., Banaschewski, T., Bokde, A.L.W., Büchel, C., Carvalho, F.M., Conrod, P.J., Flor, H., Gallinat, J., Garavan, H., Heinz, A., Jia, T., Gowland, P., Martinot, J.-L., Paus, T., Rietschel, M., Robbins, T.W., Smolka, M., Schumann, G. \& Stephens, D.N. (2017) GABRB1 Single Nucleotide Polymorphism Associated with Altered Brain Responses (but not Performance) during Measures of Impulsivity and Reward Sensitivity in Human Adolescents. Front Behav Neurosci 11, 24.

Enoch, M.-A., Hodgkinson, C.A., Yuan, Q., Shen, P.-H., Goldman, D. \& Roy, A. (2010) The influence of GABRA2, childhood trauma, and their interaction on alcohol, heroin, and cocaine dependence. Biol Psychiatry 67, 20-27.

Gelernter, J., Sherva, R., Koesterer, R., Almasy, L., Zhao, H., Kranzler, H.R. \& Farrer, L. (2014) Genome-wide association study of cocaine dependence and related traits: FAM53B identified as a risk gene. MolPsychiatry 19, 717-723.

Goldberg, L.R., Kirkpatrick, S.L., Yazdani, N., Luttik, K.P., Lacki, O.A., Babbs, R.K., Jenkins, D.F., Johnson, W.E. \& Bryant, C.D. (2017) Casein kinase 1-epsilon deletion increases mu opioid receptor-dependent behaviors and binge eating1. Genes Brain Behav 16, 725-738.

Goldman, D., Oroszi, G. \& Ducci, F. (2005) The genetics of addictions: uncovering the genes. NatRevGenet 6, 521-532.

Gonzales, N.M., Seo, J., Hernandez Cordero, A.I., St Pierre, C.L., Gregory, J.S., Distler, M.G., Abney, M., Canzar, S., Lionikas, A. \& Palmer, A.A. (2018) Genome wide association analysis in a mouse advanced intercross line. Nat Commun 9, 5162.

Haeussler, M., Schönig, K., Eckert, H., Eschstruth, A., Mianné, J., Renaud, J.-B., Schneider-Maunoury, S., Shkumatava, A., Teboul, L., Kent, J., Joly, J.-S. \& Concordet, J.-P. (2016) Evaluation of off-target and on-target scoring algorithms and integration into the guide RNA selection tool CRISPOR. Genome Biol $17,148$.

Harkness, J.H., Shi, X., Janowsky, A. \& Phillips, T.J. (2015) Trace Amine-Associated Receptor 1 Regulation of Methamphetamine Intake and Related Traits. Neuropsychopharmacology 40, 2175-2184.

Hawkins, N.A., Nomura, T., Duarte, S., Barse, L., Williams, R.W., Homanics, G.E., Mulligan, M.K., Contractor, A. \& Kearney, J.A. (2021) Gabra2 is a genetic modifier of Dravet syndrome in mice. Mamm Genome.

Ho, M.K., Goldman, D., Heinz, A., Kaprio, J., Kreek, M.J., Li, M.D., Munafo, M.R. \& Tyndale, R.F. (2010) Breaking barriers in the genomics and pharmacogenetics of drug addiction. ClinPharmacolTher $\mathbf{8 8}$, 779-791. 

available under aCC-BY-NC-ND 4.0 International license.

Hörtnagl, H., Tasan, R.O., Wieselthaler, A., Kirchmair, E., Sieghart, W. \& Sperk, G. (2013) Patterns of mRNA and protein expression for 12 GABAA receptor subunits in the mouse brain. Neuroscience 236, 345372.

Jensen, K.P. (2016) A Review of Genome-Wide Association Studies of Stimulant and Opioid Use Disorders. MolNeuropsychiatry 2, 37-45.

Jimenez Chavez, C.L., Bryant, C.D., Munn-Chernoff, M.A. \& Szumlinski, K.K. (2021) Selective Inhibition of PDE4B Reduces Binge Drinking in Two C57BL/6 Substrains. Int J Mol Sci 22.

Kanaide, M., Uezono, Y., Matsumoto, M., Hojo, M., Ando, Y., Sudo, Y., Sumikawa, K. \& Taniyama, K. (2007) Desensitization of $\mathrm{GABA}(\mathrm{B})$ receptor signaling by formation of protein complexes of $\mathrm{GABA}(\mathrm{B} 2)$ subunit with GRK4 or GRK5. J Cell Physiol 210, 237-245.

Keane, T.M., Goodstadt, L., Danecek, P., White, M.A., Wong, K., Yalcin, B., Heger, A., Agam, A., Slater, G., Goodson, M., Furlotte, N.A., Eskin, E., Nellaker, C., Whitley, H., Cleak, J., Janowitz, D., HernandezPliego, P., Edwards, A., Belgard, T.G., Oliver, P.L., Mclntyre, R.E., Bhomra, A., Nicod, J., Gan, X., Yuan, W., van der Weyden, L., Steward, C.A., Bala, S., Stalker, J., Mott, R., Durbin, R., Jackson, I.J., Czechanski, A., Guerra-Assuncao, J.A., Donahue, L.R., Reinholdt, L.G., Payseur, B.A., Ponting, C.P., Birney, E., Flint, J. \& Adams, D.J. (2011) Mouse genomic variation and its effect on phenotypes and gene regulation. Nature 477, 289-294.

Kirkpatrick, S.L. \& Bryant, C.D. (2015) Behavioral architecture of opioid reward and aversion in C57BL/6 substrains. FrontBehavNeurosci 8, 450.

Kirkpatrick, S.L., Goldberg, L.R., Yazdani, N., Babbs, R.K., Wu, J., Reed, E.R., Jenkins, D.F., Bolgioni, A.F., Landaverde, K.I., Luttik, K.P., Mitchell, K.S., Kumar, V., Johnson, W.E., Mulligan, M.K., Cottone, P. \& Bryant, C.D. (2017) Cytoplasmic FMR1-Interacting Protein 2 Is a Major Genetic Factor Underlying Binge Eating. BiolPsychiatry 81, 757-769.

Kuleshov, M.V., Jones, M.R., Rouillard, A.D., Fernandez, N.F., Duan, Q., Wang, Z., Koplev, S., Jenkins, S.L., Jagodnik, K.M., Lachmann, A., McDermott, M.G., Monteiro, C.D., Gundersen, G.W. \& Ma'ayan, A. (2016) Enrichr: a comprehensive gene set enrichment analysis web server 2016 update. Nucleic Acids Res 44, W90-97.

Kumar, V., Kim, K., Joseph, C., Kourrich, S., Yoo, S.H., Huang, H.C., Vitaterna, M.H., de Villena, F.P., Churchill, G., Bonci, A. \& Takahashi, J.S. (2013) C57BL/6N mutation in Cytoplasmic FMRP interacting protein 2 regulates cocaine response. Science 342, 1508-1512.

Lieberman, R., Kranzler, H.R., Joshi, P., Shin, D.-G. \& Covault, J. (2015) GABRA2 Alcohol Dependence Risk Allele is Associated with Reduced Expression of Chromosome 4p12 GABAA Subunit Genes in Human Neural Cultures. Alcohol Clin Exp Res 39, 1654-1664.

Maxwell, J.C. (2020) Is Cocaine Coming Back? A Commentary. Subst Use Misuse 55, 345-348.

Miner, N.B., Elmore, J.S., Baumann, M.H., Phillips, T.J. \& Janowsky, A. (2017) Trace amine-associated receptor 1 regulation of methamphetamine-induced neurotoxicity. Neurotoxicology 63, 57-69.

Morris, H.V., Dawson, G.R., Reynolds, D.S., Atack, J.R., Rosahl, T.W. \& Stephens, D.N. (2008) Alpha2containing $\mathrm{GABA}(\mathrm{A})$ receptors are involved in mediating stimulant effects of cocaine. Pharmacol Biochem Behav 90, 9-18.

Mortazavi, M., Ren, Y., Saini, S., Antaki, D., St. Pierre, C., Williams, A., Sohni, A., Wilkinson, M., Gymrek, M., Sebat, J. \& Palmer, A. (2021) Polymorphic SNPs, short tandem repeats and structural variants are responsible for differential gene expression across C57BL/6 and C57BL/10 substrains. BioRxiv. 
Mulligan, M.K., Abreo, T., Neuner, S.M., Parks, C., Watkins, C.E., Houseal, M.T., Shapaker, T.M., Hook, M., Tan, H., Wang, X., Ingels, J., Peng, J., Lu, L., Kaczorowski, C.C., Bryant, C.D., Homanics, G.E. \& Williams, R.W. (2019) Identification of a functional non-coding variant in the GABAA receptor a2 subunit of the C57BL/6J mouse reference genome: Major implications for neuroscience research. Frontiers in Genetics 540211.

Mulligan, M.K., Mozhui, K., Prins, P. \& Williams, R.W. (2017) GeneNetwork: A Toolbox for Systems Genetics. Methods MolBiol 1488, 75-120.

Mulligan, M.K., Ponomarev, I., Boehm, S.L., 2nd, Owen, J.A., Levin, P.S., Berman, A.E., Blednov, Y.A., Crabbe, J.C., Williams, R.W., Miles, M.F. \& Bergeson, S.E. (2008) Alcohol trait and transcriptional genomic analysis of C57BL/6 substrains. Genes Brain Behav 7, 677-689.

National Research Council (US) Committee for the Update of the Guide for the Care and Use of Laboratory Animals. (2011) Guide for the Care and Use of Laboratory Animals. , The National Academies Collection: Reports funded by National Institutes of Health. 8th edn. National Academies Press (US), Washington (DC).

Olsen, R.W. \& Sieghart, W. (2008) International Union of Pharmacology. LXX. Subtypes of gammaaminobutyric acid $(\mathrm{A})$ receptors: classification on the basis of subunit composition, pharmacology, and function. Update. Pharmacol Rev 60, 243-260.

Panzanelli, P., Gunn, B.G., Schlatter, M.C., Benke, D., Tyagarajan, S.K., Scheiffele, P., Belelli, D., Lambert, J.J., Rudolph, U. \& Fritschy, J.-M. (2011) Distinct mechanisms regulate GABAA receptor and gephyrin clustering at perisomatic and axo-axonic synapses on CA1 pyramidal cells. J Physiol 589, 4959-4980.

Parker, C.C., Gopalakrishnan, S., Carbonetto, P., Gonzales, N.M., Leung, E., Park, Y.J., Aryee, E., Davis, J., Blizard, D.A., Ackert-Bicknell, C.L., Lionikas, A., Pritchard, J.K. \& Palmer, A.A. (2016) Genome-wide association study of behavioral, physiological and gene expression traits in outbred CFW mice. NatGenet.

Peris, J. (1996) Repeated cocaine injections decrease the function of striatal gamma-aminobutyric acid(A) receptors. J Pharmacol Exp Ther 276, 1002-1008.

Peris, J., Jung, B.J., Resnick, A., Walker, P., Malakhova, O., Bokrand, Y. \& Wielbo, D. (1998) Antisense inhibition of striatal GABAA receptor proteins decreases GABA-stimulated chloride uptake and increases cocaine sensitivity in rats. Brain Res Mol Brain Res 57, 310-320.

Peterson, R. \& Cavanaugh, J. (2019) Ordered quantile normalization: a semiparametric transformation built for the cross-validation era. Journal of Applied Statistics 1-16.

Phillips, T.J., Kamens, H.M. \& Wheeler, J.M. (2008) Behavioral genetic contributions to the study of addictionrelated amphetamine effects. Neuroscience and biobehavioral reviews 32, 707-59.

Reed, C., Baba, H., Zhu, Z., Erk, J., Mootz, J.R., Varra, N.M., Williams, R.W. \& Phillips, T.J. (2017) A Spontaneous Mutation in Taar1 Impacts Methamphetamine-Related Traits Exclusively in DBA/2 Mice from a Single Vendor. Front Pharmacol 8, 993.

Resnick, A., Homanics, G.E., Jung, B.J. \& Peris, J. (1999) Increased acute cocaine sensitivity and decreased cocaine sensitization in GABA(A) receptor beta3 subunit knockout mice. J Neurochem 73, 1539-1548.

Rhinehart, E.M., Nentwig, T.B., Wilson, D.E., Leonard, K.T., Chaney, B.N. \& Grisel, J.E. (2018) Sex and $\beta-$ Endorphin Influence the Effects of Ethanol on Limbic Gabra2 Expression in a Mouse Binge Drinking Model. Front Genet 9, 567.

Ruan, Q.T., Yazdani, N., Blum, B.C., Beierle, J.A., Lin, W., Coelho, M.A., Fultz, E.K., Healy, A.F., Shahin, J.R., Kandola, A.K., Luttik, K.P., Zheng, K., Smith, N.J., Cheung, J., Mortazavi, F., Apicco, D.J., Ragu 
bioRxiv preprint doi: https://doi.org/10.1101/2021.06.29.450337; this version posted June 30, 2021. The copyright holder for this preprint (which was not certified by peer review) is the author/funder, who has granted bioRxiv a license to display the preprint in perpetuity. It is made available under aCC-BY-NC-ND 4.0 International license.

Varman, D., Ramamoorthy, S., Ash, P.E.A., Rosene, D.L., Emili, A., Wolozin, B., Szumlinski, K.K. \& Bryant, C.D. (2020a) A Mutation in Hnrnph1 That Decreases Methamphetamine-Induced Reinforcement, Reward, and Dopamine Release and Increases Synaptosomal hnRNP H and Mitochondrial Proteins. J Neurosci 40, 107-130.

Ruan, Q.T., Yazdani, N., Reed, E.R., Beierle, J.A., Peterson, L.P., Luttik, K.P., Szumlinski, K.K., Johnson, W.E., Ash, P.E.A., Wolozin, B. \& Bryant, C.D. (2020b) 5' UTR variants in the quantitative trait gene Hnrnph1 support reduced 5' UTR usage and hnRNP H protein as a molecular mechanism underlying reduced methamphetamine sensitivity. FASEB J 34, 9223-9244.

Schwarzer, C., Berresheim, U., Pirker, S., Wieselthaler, A., Fuchs, K., Sieghart, W. \& Sperk, G. (2001) Distribution of the major gamma-aminobutyric acid(A) receptor subunits in the basal ganglia and associated limbic brain areas of the adult rat. J Comp Neurol 433, 526-549.

Sen, S., Satagopan, J.M., Broman, K.W. \& Churchill, G.A. (2007) R/qtIDesign: inbred line cross experimental design. MammGenome 18, 87-93.

Shi, X., Walter, N.A.R., Harkness, J.H., Neve, K.A., Williams, R.W., Lu, L., Belknap, J.K., Eshleman, A.J., Phillips, T.J. \& Janowsky, A. (2016) Genetic Polymorphisms Affect Mouse and Human Trace AmineAssociated Receptor 1 Function. PLOS ONE 11, e0152581.

Simon, M.M., Greenaway, S., White, J.K., Fuchs, H., Gailus-Durner, V., Sorg, T., Wong, K., Bedu, E., Cartwright, E.J., Dacquin, R., Djebali, S., Estabel, J., Graw, J., Ingham, N.J., Jackson, I.J., Lengeling, A., Mandillo, S., Marvel, J., Meziane, H., Preitner, F., Puk, O., Roux, M., Adams, D.J., Atkins, S., Ayadi, A., Becker, L., Blake, A., Brooker, D., Cater, H., Champy, M.F., Combe, R., Danecek, P., di Fenza, A., Gates, H., Gerdin, A.K., Golini, E., Hancock, J.M., Hans, W., Holter, S.M., Hough, T., Jurdic, P., Keane, T.M., Morgan, H., Muller, W., Neff, F., Nicholson, G., Pasche, B., Roberson, L.A., Rozman, J., Sanderson, M., Santos, L., Selloum, M., Shannon, C., Southwell, A., Tocchini-Valentini, G.P., Vancollie, V.E., Wells, S., Westerberg, H., Wurst, W., Zi, M., Yalcin, B., Ramirez-Solis, R., Steel, K.P., Mallon, A.M., Hrab 283 de Angelis, M., Herault, Y. \& Brown, S.D. (2013) A comparative phenotypic and genomic analysis of C57BL/6J and C57BL/6N mouse strains. Genome Biol 14, R82.

Smelson, D., Yu, L., Buyske, S., Gonzalez, G., Tischfield, J., Deutsch, C.K. \& Ziedonis, D. (2012) Genetic association of GABA-A receptor alpha-2 and mu opioid receptor with cocaine cue-reactivity: evidence for inhibitory synaptic neurotransmission involvement in cocaine dependence. Am J Addict 21, 411415.

Stephens, D.N., King, S.L., Lambert, J.J., Belelli, D. \& Duka, T. (2017) GABAA receptor subtype involvement in addictive behaviour. Genes Brain Behav 16, 149-184.

Tamaki, R., Yoshikawa, M., Shinomiya, T., Andoh, H., Kawaguchi, M., Hashimoto, A., Byrne, D.W. \& Kobayashi, $H$. (2008) Chronic administration of methamphetamine increases the mRNA expression of diazepam binding inhibitor in rat brain. Tokai J Exp Clin Med 33, 46-50.

Wager, T.T., Chandrasekaran, R.Y., Bradley, J., Rubitski, D., Berke, H., Mente, S., Butler, T., Doran, A., Chang, C., Fisher, K., Knafels, J., Liu, S., Ohren, J., Marconi, M., DeMarco, G., Sneed, B., Walton, K., Horton, D., Rosado, A. \& Mead, A. (2014) Casein kinase $1 \delta / \varepsilon$ inhibitor PF-5006739 attenuates opioid drug-seeking behavior. ACS Chem Neurosci 5, 1253-1265.

Yalcin, B., Wong, K., Agam, A., Goodson, M., Keane, T.M., Gan, X., Nellaker, C., Goodstadt, L., Nicod, J., Bhomra, A., Hernandez-Pliego, P., Whitley, H., Cleak, J., Dutton, R., Janowitz, D., Mott, R., Adams, D.J. \& Flint, J. (2011) Sequence-based characterization of structural variation in the mouse genome. Nature 477, 326-329.

Yazdani, N., Parker, C.C., Shen, Y., Reed, E.R., Guido, M.A., Kole, L.A., Kirkpatrick, S.L., Lim, J.E., Sokoloff, G., Cheng, R., Johnson, W.E., Palmer, A.A. \& Bryant, C.D. (2015) Hnrnph1 Is A Quantitative Trait Gene for Methamphetamine Sensitivity. PLoS Genet 11, e1005713. 
Table 1. Cis-eQTL gene transcripts showing peak marker association in transcript variance with rs29547790 (chromosome 5: $70.9 \mathrm{Mb}$ (FDR < 0.05)

\begin{tabular}{|c|c|c|c|c|c|}
\hline Gene & $\begin{array}{l}\text { Chr.5 location } \\
(\mathrm{Mb})\end{array}$ & $\begin{array}{l}\text { Distance from } \\
\text { rs29547790 (Mb) }\end{array}$ & $\begin{array}{l}\text { Log2FC } \\
\text { (JJ vs. NN) }\end{array}$ & P-value & Adjusted P-value \\
\hline Gabra2 & 70.96 & 0.026 & -0.88 & 1.66E-30 & $7.24 E-27$ \\
\hline Muc3a & 137.21 & 66.28 & 0.56 & $2.60 \mathrm{E}-10$ & 1.14E-07 \\
\hline Atp8a1 & 67.62 & 3.08 & 0.18 & 1.28E-06 & 9.57E-05 \\
\hline Ptpn11 & 121.13 & 50.20 & 0.16 & 2.17E-05 & 0.000778 \\
\hline Cxcl5 & 90.76 & 19.83 & -2.41 & 3.22E-05 & 0.001042 \\
\hline Fgfr3 & 33.72 & 37.19 & 0.19 & 0.000123 & 0.002843 \\
\hline Cux2 & 121.86 & 50.92 & -0.33 & 0.000136 & 0.003049 \\
\hline Ankrd13a & 114.77 & 43.84 & 0.27 & 0.00029 & 0.005321 \\
\hline Whsc1 & 33.82 & 37.03 & -0.14 & 0.000399 & 0.006869 \\
\hline $\mathrm{Mn} 1$ & 111.42 & 40.49 & 0.24 & 0.000644 & 0.009812 \\
\hline Auts2 & 131.44 & 60.51 & 0.20 & 0.000721 & 0.01069 \\
\hline Cds1 & 101.77 & 30.83 & -0.09 & 0.002214 & 0.02399 \\
\hline Lrrc8c & 105.52 & 34.59 & 0.22 & 0.002975 & 0.0293 \\
\hline Tsc22d4 & 137.75 & 66.81 & 0.04 & 0.005113 & 0.043141 \\
\hline Garem2 & 30.11 & 40.81 & 0.23 & 0.005705 & 0.046604 \\
\hline
\end{tabular}

Red rows $=$ decreased expression with the C57BL/6J allele versus the C57BL/6NJ allele; blue rows = increased expression with the C57BL/6J allele versus the C57BL/6NJ allele 
bioRxiv preprint doi: https://doi.org/10.1101/2021.06 29.450337; this version posted June 30,2021 . The copyright holder for this preprint (which was not certified by peer review) is the author/funder, who has granted bioRxiv a license to display the preprint in perpetuity. It is made available under aCC-BY-NC-ND 4.0 International license.

Table 2. Enrichment analysis of genes correlated with Gabra2 transcript levels in F2 mice ( $n=23$; $r \leq-$

0.5 or $r \geq+0.5 ; p \geq 0.015)$

GO: BIOLOGICAL PROCESS

\begin{tabular}{|c|c|c|c|c|c|c|c|}
\hline Term & GO \# & Overlap & P-value & Adj. $P$ & Z-score & $\begin{array}{l}\text { Combined } \\
\text { Score }\end{array}$ & Genes \\
\hline $\begin{array}{l}\text { synaptic } \\
\text { transmission } \\
\text {, GABAergic }\end{array}$ & 51932 & $3 / 12$ & 7.83E-05 & 0.05354 & -2.45 & 23.13 & GABRA2;GABRE;GABRG3 \\
\hline $\begin{array}{l}\text { GABA } \\
\text { signaling } \\
\text { pathway }\end{array}$ & 7214 & $3 / 20$ & $3.89 \mathrm{E}-04$ & 0.132938 & -2.06 & 16.21 & GABRA2;GABRE;GABRG3 \\
\hline $\begin{array}{l}\text { L-amino } \\
\text { acid } \\
\text { transport }\end{array}$ & 15807 & $3 / 26$ & 8.59E-04 & 0.195793 & -2.22 & 15.68 & PRAF2;SLC3A2;SLC38A5 \\
\hline $\begin{array}{l}\text { regulation of } \\
\text { postsynaptic } \\
\text { membrane } \\
\text { potential }\end{array}$ & 60078 & $3 / 34$ & $1.89 \mathrm{E}-03$ & 0.257775 & -1.51 & 9.49 & GABRA2;GABRE;GABRG3 \\
\hline $\begin{array}{l}\text { chemical } \\
\text { synaptic } \\
\text { transmission } \\
\text { postsynaptic }\end{array}$ & 99565 & $3 / 34$ & 1.89E-03 & 0.257775 & -1.45 & 9.09 & GABRA2;GABRE;GABRG3 \\
\hline \multicolumn{8}{|c|}{ GO: CELLULAR COMPONENT } \\
\hline Term & GO \# & Overlap & P-value & Adj. $P$ & Z-score & $\begin{array}{l}\text { Combined } \\
\text { Score }\end{array}$ & Genes \\
\hline $\begin{array}{l}\text { GABA-A } \\
\text { receptor } \\
\text { complex }\end{array}$ & 1902711 & $3 / 20$ & 3.89E-04 & 0.023457 & -2.19 & 17.20 & GABRA2:GABRE;GABRG3 \\
\hline $\begin{array}{l}\text { dendrite } \\
\text { membrane }\end{array}$ & 32590 & $3 / 21$ & $4.51 \mathrm{E}-04$ & 0.023457 & -2.78 & 21.38 & GABRA2;GABRE;GABRG3 \\
\hline germ plasm & 60293 & $2 / 14$ & $4.49 \mathrm{E}-03$ & 0.123421 & -2.36 & 12.75 & TDRD1;SNRPG \\
\hline cytoskeleton & 5856 & $10 / 521$ & $4.75 \mathrm{E}-03$ & 0.123421 & -1.58 & 8.45 & $\begin{array}{l}\text { BCAS3;ACTR1A;EDA;MYO } \\
\text { T;MVP;SHROOM2;MYOZ3; } \\
\text { NPM3;S100A9;MDN1 }\end{array}$ \\
\hline P granule & 43186 & $2 / 17$ & 6.61E-03 & 0.137495 & -2.35 & 11.81 & TDRD1;SNRPG \\
\hline $\begin{array}{l}\text { GO: MOLEC } \\
\text { Term }\end{array}$ & $\begin{array}{l}\text { LAR FUN } \\
\text { GO \# }\end{array}$ & $\begin{array}{l}\text { TION } \\
\text { Overlap }\end{array}$ & $\mathrm{P}$-value & Adj. $P$ & Z-score & $\begin{array}{l}\text { Combined } \\
\text { Score }\end{array}$ & Genes \\
\hline $\begin{array}{l}\text { benzodiaze } \\
\text { pine } \\
\text { receptor } \\
\text { activity }\end{array}$ & 8503 & $3 / 11$ & $5.90 \mathrm{E}-05$ & 0.009565 & -2.81 & 27.34 & GABRA2;GABRE;GABRG3 \\
\hline $\begin{array}{l}\text { GABA-gated } \\
\text { chloride ion } \\
\text { channel } \\
\text { activity }\end{array}$ & 22851 & $3 / 13$ & $1.01 \mathrm{E}-04$ & 0.009565 & -2.49 & 22.93 & GABRA2;GABRE;GABRG3 \\
\hline
\end{tabular}


bioRxiv preprint doi: https://doi org/10.1101/2021.06.29.450337; this version posted June 30, 2021. The copyright holder for this preprint (which was not certified by peer review) is the author/funder, who has granted bioRxiv a license to display the preprint in perpetuity. It is made available under aCC-BY-NC-ND 4.0 International license.

\begin{tabular}{|l|l|l|l|l|l|l|l|}
\hline $\begin{array}{l}\text { inhibitory } \\
\text { extracellular } \\
\text { ligand-gated } \\
\text { ion channel } \\
\text { activity }\end{array}$ & 5237 & $3 / 16$ & $1.95 \mathrm{E}-04$ & 0.012288 & -2.39 & 20.38 & GABRA2;GABRE;GABRG3 \\
\hline $\begin{array}{l}\text { ligand-gated } \\
\text { anion } \\
\text { channel } \\
\text { activity }\end{array}$ & 99095 & $3 / 19$ & $3.32 \mathrm{E}-04$ & 0.014028 & -2.16 & 17.29 & GABRA2;GABRE;GABRG3 \\
\hline $\begin{array}{l}\text { GABA-A } \\
\text { receptor } \\
\text { activity }\end{array}$ & 4890 & $3 / 20$ & $3.89 \mathrm{E}-04$ & 0.014028 & -2.09 & 16.42 & GABRA2;GABRE;GABRG3 \\
\hline
\end{tabular}


bioRxiv preprint doi: https://doi.org/10.1101/2021.06.29.450337; this version posted June 30, 2021. The copyright holder for this preprint (which was not certified by peer review) is the author/funder, who has granted bioRxiv a license to display the preprint in perpetuity. It is made available under aCC-BY-NC-ND 4.0 International license.

Table 3. Pearson's $r$ for genes identified from enrichment analysis (see Table 2) that were correlated with Gabra2

\begin{tabular}{|c|c|c|c|c|c|}
\hline Gene & Name & chr & start & $\mathbf{r}$ & p.value \\
\hline Gabra2 & $\begin{array}{l}\text { gamma-aminobutyric acid } \quad \text { (GABA) } A \\
\text { receptor, subunit } \alpha 2\end{array}$ & 5 & 70.96 & 1.00 & 0 \\
\hline Myot & myotilin & 18 & 44.33 & 0.63 & 0.001 \\
\hline Hba-a1 & hemoglobin alpha, adult chain 1 & 11 & 32.28 & -0.62 & 0.002 \\
\hline Eda & ectodysplasin- $A$ & $\mathrm{X}$ & 99.98 & 0.62 & 0.002 \\
\hline Npm3 & nucleoplasmin 3 & 19 & 45.75 & 0.59 & 0.003 \\
\hline Slc38a5 & solute carrier family 38, member 5 & $\mathrm{X}$ & 8.27 & -0.59 & 0.003 \\
\hline Mdn1 & midasin AAA ATPase 1 & 4 & 32.66 & 0.56 & 0.005 \\
\hline Gabre & $\begin{array}{l}\text { gamma-aminobutyric acid } \text { (GABA) A } \\
\text { receptor, subunit } \square\end{array}$ & $x$ & 72.23 & 0.56 & 0.005 \\
\hline Shroom2 & shroom family member 2 & $\mathrm{X}$ & 152.6 & -0.56 & 0.005 \\
\hline Myoz3 & myozenin 3 & 18 & 60.57 & 0.56 & 0.006 \\
\hline Snrpg & small nuclear ribonucleoprotein polypeptide G & 6 & 86.37 & 0.56 & 0.006 \\
\hline Hba-a2 & hemoglobin $\alpha$, adult chain 2 & 11 & 32.3 & -0.55 & 0.006 \\
\hline $\mathrm{Hbb}-\mathrm{bs}$ & hemoglobin, $\beta$ adult s chain & 7 & 103.8 & -0.53 & 0.009 \\
\hline S100a9 & S100 calcium binding protein A9 & 3 & 90.69 & -0.53 & 0.01 \\
\hline Actr1a & ARP1 actin-related protein $1 \mathrm{~A}$, centractin $\alpha$ & 19 & 46.38 & -0.52 & 0.01 \\
\hline Mvp & major vault protein & 7 & 127 & -0.52 & 0.011 \\
\hline Bcas3 & breast carcinoma amplified sequence 3 & 11 & 85.35 & -0.52 & 0.012 \\
\hline Grk5 & G protein-coupled receptor kinase 5 & 19 & 60.89 & 0.51 & 0.013 \\
\hline Praf2 & PRA1 domain family 2 & $\mathrm{X}$ & 7.73 & 0.51 & 0.014 \\
\hline Slc3a2 & solute carrier family 3 , member 2 & 19 & 8.71 & -0.51 & 0.014 \\
\hline Tdrd1 & tudor domain containing 1 & 19 & 56.83 & -0.50 & 0.014 \\
\hline Gabrg3 & $\begin{array}{l}\text { gamma-aminobutyric acid }(\text { GABA) A } \\
\text { receptor, subunit } \mathrm{Y} 3\end{array}$ & 7 & 56.72 & 0.50 & 0.014 \\
\hline
\end{tabular}

Blue rows indicate positive correlation with Gabra2 expression; red rows indicate negative correlation with Gabra2 expression. 


\section{FIGURE LEGENDS}

Figure 1. Maximum speed and distance traveled in response to saline (Days 1-2) and methamphetamine (Days 3-5) in the parental C57BL/6J (B6J) and C57BL/6NJ (B6NJ) substrains. (A): Sex-combined maximum speed $(\mathrm{m} / \mathrm{s})$ across training days. RM ANOVA across days indicated a main effect of Substrain $\left(F_{1,59}=59.96, p=1.49 \times 10^{-10}\right)$, Sex $\left(F_{1,59}=18.02, p=7.85 \times 10^{-5}\right)$, Day $\left(F_{4,236}=377.90, p<2 \times 10^{-}\right.$ $\left.{ }^{16}\right)$, and a Substrain $x$ Day interaction $\left(\mathrm{F}_{4,236}=24.51, \mathrm{p}<2 \times 10^{-16}\right)$. Tukey's post-hoc revealed a significant increase in maximum speed in B6J vs. B6NJ mice on Day(D) 3, D4, and D5 ( ${ }^{*}$ all p'sadjusted < 0.0001). (B): Maximum speed $(\mathrm{m} / \mathrm{s})$ across training days in females. RM ANOVA indicated a main effect of Substrain $\left(F_{1,30}=\right.$ 22.29, $\left.p=5.11 \times 10^{-5}\right)$, Day $\left(F_{4,120}=199.44, p<2 \times 10^{-16}\right)$, and a Substrain $\times$ Day interaction $\left(F_{4,120}=13.21, p=\right.$ $\left.6 \times 10^{-9}\right)$. Tukey's post-hoc test revealed a significant difference increase in maximum speed in B6J vs. B6NJ females on D3 ( $\left.{ }^{*} p_{\text {adjusted }}=0.0005\right)$, D4, and D5 ( ${ }^{*} p^{\prime}$ sadjusted $_{<0.0001)}$. (C): Maximum speed across training days in males. RM ANOVA indicated a main effect of Substrain $\left(F_{1,29}=38.67, p=8.75 \times 10^{-7}\right)$, Day $\left(F_{4,116}=178.66\right.$, $\left.\mathrm{p}<2 \times 10^{-16}\right)$, and a Substrain $\times$ Day interaction $\left(F_{4,116}=11.67, p=5.36 \times 10^{-8}\right)$. Tukey's post-hoc revealed a significant increase in maximum speed in B6J versus B6NJ males on D1 ( $p_{\text {adjusted }}=0.03$ ), D3, D4, and D5

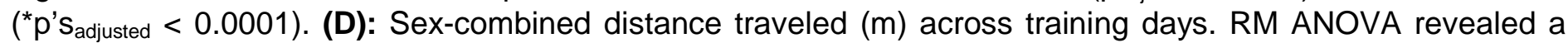
main effect of Substrain $\left(F_{1,59}=82.39, p=8.51 \times 10^{-13}\right)$, Day $\left(F_{4,236}=798.0, p<2 \times 10^{-16}\right)$, a Substrain $\times$ Day interaction $\left(F_{4,236}=67.99, p<2 \times 10^{-16}\right)$, and a Sex $x$ Day interaction $\left(F_{4,236}=6.46 ; p=6.0 \times 10^{-5}\right)$. Tukey's post-hoc revealed a significant increase in distance traveled in B6J vs. B6NJ mice on D3, D4, and D5 (all $\left.\mathrm{p} \mathrm{S}_{\text {adjusted }}<0.0001\right)$. (E): Distance traveled across training days in females. RM ANOVA indicated a main effect of Substrain $\left(F_{1,30}=41.18, p=4.37 \times 10^{-7}\right)$, Day $\left(F_{4,120}=408,83, p<2 \times 10^{-16}\right)$, and a Substrain $x$ Day interaction $\left(F_{4,120}=27.05, p=5.27 \times 10^{-10}\right)$. Tukey's post-hoc revealed a significant increase in distance traveled in B6J vs. B6NJ females on D3, D4, and D5 ( ${ }^{*}$ all p's adjusted $\left._{2} 0.0001\right)$. (F): Distance traveled across training days in males. RM ANOVA indicated a main effect of Substrain $\left(F_{1,29}=40.16, p=6.34 \times 10^{-7}\right)$, Day $\left(F_{4,116}=396.98, p<2 \times 10^{-16}\right)$, and a Substrain $\times$ Day interaction $\left(F_{4,116}=44.59, p<2 \times 10^{-16}\right)$. Tukey's post-hoc test revealed a significant increase in distance traveled in B6J vs. B6NJ males on Day 3, Day 4, and Day 5 ( ${ }^{*}$ all p's adjusted $_{2}$ 0.0001).

Figure 2. Genome-wide significant QTL on chromosome 11 near Cyfip2 underlying variation in sensitized methamphetamine-induced maximum speed. Mice were treated on Day(D) 1 and D2 with saline (i.p.) and on D3, D4, and D5 with methamphetamine (2 mg/kg, i.p.) and behavioral activity was recorded over 30 min. (A): Genome-wide significant QTL on chromosome 11 for maximum speed following the second methamphetamine injection (2 mg/kg, i.p.) on D4 [LOD = 3.5, peak = $21 \mathrm{cM}$ (36 Mb); Bayes interval: 18-39 cM (31-63 Mb); $11 \%$ of the phenotypic variance explained] and following the third methamphetamine injection (2 $\mathrm{mg} / \mathrm{kg}$, i.p.) on D5 [LOD = 4.2, peak = $21 \mathrm{cM}(36 \mathrm{Mb})$; Bayes interval: $18-34 \mathrm{cM}(31-57 \mathrm{Mb})$; $11 \%$ of the phenotypic variance explained]. Solid horizontal lines for panels A and B indicate significance thresholds for each phenotype $(p<0.05)$. (B): Chromosome 11 QTL plot for maximum speed on D1 through D5. (C): Effect plot of maximum speed as a function of Genotype at the peak locus for maximum speed on D1 through D5. $\mathrm{J}=$ homozygous for $\mathrm{B} 6 \mathrm{~J}$ allele; $\mathrm{BN}=$ heterozygous; $\mathrm{N}=$ homozygous for $\mathrm{B} 6 \mathrm{NJ}$ allele.

Figure 3. Genome-wide significant QTL on chromosome 5 near Gabra2 underlying variation in acute methamphetamine-induced distance traveled. (A): Genome-wide significant QTL on chromosome 5 for distance traveled $(\mathrm{m})$ on Day(D) 2 over 30 min following i.p. saline [LOD = 3.8, peak = $22 \mathrm{cM}(41 \mathrm{Mb})$; Bayes interval: $22 \mathrm{cM}$ (41 Mb); Bayes: 14-34 cM (29-66 Mb); 10\% of the phenotypic variance explained], a second QTL for distance traveled D3 following $2 \mathrm{mg} / \mathrm{kg}$ methamphetamine [LOD = 5.2, peak = $35 \mathrm{cM}$ (67 Mb); Bayes interval: $32-47 \mathrm{cM}$ (60-95 Mb); 14\% of the phenotypic variance explained], and a third QTL on D4 following the second methamphetamine injection [LOD = 3.6; peak = $34 \mathrm{cM}$ (66 Mb); Bayes: 16-46 cM (30-93 Mb); 12\% of the phenotypic variance explained]. Solid horizontal lines for panels A and B indicate significance threshold for each phenotype $(p<0.05)$. (B): Chromosome 5 QTL plot for distance traveled on D1 through D5. (C): Effect plot of total distance traveled for D1 through D5 over $30 \mathrm{~min}$ at the peak associated marker (rs29547790; 70.93 $\mathrm{Mb}$ ). (D): Time course in 5-min bins of the effect plot for acute methamphetamine-induced distance traveled on D3. RM ANOVA indicated a main effect of Genotype $\left(F_{2,174}=7.20 ; p=0.001\right)$, Sex $\left(F_{1,174}=3.89 ; p=0.05\right)$, Time $\left(F_{5,870}=485.02 ; p<2 \times 10^{-16}\right)$, a Genotype $x$ Time interaction $\left(F_{10,870}=2.39 ; p=0.0085\right)$ but no interactions with Sex (p's > 0.46). * = significant increase in $\mathrm{J} / \mathrm{J}$ relative $\mathrm{J} / \mathrm{N}$ and N/N (Tukey's $p_{\text {adjusted }}<0.05$ for 
the three comparisons at each time point). (E): Time-course in females. RM ANOVA indiated no effect of Genotype $\left(F_{2,103}=2.13\right)$, an effect of Time $\left(F_{5,515}=290.22 ; p<2 \times 10^{-16}\right)$, and no interaction $(p=0.51)$. Simple contrasts did not identify any significant differences among genotypes at any time point (p's > 0.05). (F): Timecourse in males. There was a main effect of Genotype $\left(F_{2,71}=7.49 ; p=0.0011\right)$, Time $\left(F_{5,355}=195.53 ; p<2 x\right.$ $\left.10^{-16}\right)$, and a Genotype $x$ Time interaction $\left(F_{10,355}=1.85 ; p=0.05\right) .{ }^{*}=$ significant increase in $\mathrm{J} / \mathrm{J}$ relative $\mathrm{J} / \mathrm{N}$ and N/N (Tukey's $p_{\text {adjusted }}<0.05$ for the three comparisons at each time point). $J=$ homozygous for B6J allele; $\mathrm{BN}=$ heterozygous; $\mathrm{N}=$ homozygous for B6NJ allele. Green, dashed traces denote distance traveled on D3.

Figure 4. Identification of a quantitative trait variant in Gabra2 that underlies variation in methamphetamine stimulant sensitivity as measured via distance traveled. (A): Schematic of geneedited knockin (KI) of the single T nucleotide "corrected" allele that was inserted into intron 4 of the Gabra2 gene. The C57BL/6J (B6J) substrain harbors a single nucleotide T deletion on chromosome 5 at 71,041,638 bp (mm10). CRISPR-Cas9 was used to insert the deleted T nucleotide onto the B6J genome thus "correcting" the single nucleotide deletion. (B): Distance traveled across Day(D) 1 through D5 in Gabra2 KI vs. B6J wildtypes. RM ANOVA of the sex-combined data revealed a main effect of Genotype $\left(F_{1,31}=9.63, p=0.0041\right)$, Day $\left(F_{4,124}=177.28, p<2 \times 10^{-16}\right)$, and a Genotype $x$ Day interaction $\left(F_{4,124}=7.36, p=2.37 \times 10^{-5}\right)$. There was no statistically significant effect of $\operatorname{Sex}\left(F_{1,31}=2.77 ; p=0.11\right)$. Furthermore, the interaction of Sex with Day $\left(F_{4,124}=2.25 ; p=0.068\right)$ and the Genotype $x$ Sex $x$ Day interaction $\left(F_{4,124}=2.09 ; p=0.087\right)$ did not reach statistical significance. Simple contrasts of the sex-combined data revealed a significant decrease in distance traveled in KI vs. B6J mice on D3 ( $\left.{ }^{*} p=0.0063\right)$, D4 ( $\left.{ }^{*} p<0.0001\right)$, and D5 ( $\left.{ }^{*} p=0.0001\right)$. (C): Distance traveled in females. RM ANOVA indicated a main effect of Day $\left(F_{4,56}=73.86, p<2 \times 10^{-16}\right)$ and a Genotype $x$ Day interaction $\left(F_{4,56}=3.38, p=0.015\right)$. Simple contrasts identified a significant decrease in distance traveled in Gabra2 KI females vs. B6J wild-type females on D4 ( $\left.{ }^{*} p=0.0498\right)$ and D5 ( $\left.{ }^{*} p=0.0009\right)$. (D): Distance traveled in males. RM ANOVA indicated a main effect of Genotype $\left(F_{1,17}=6.49, p=0.021\right)$, Day $\left(F_{4,68}=109.21, p<2 x\right.$ $\left.10^{-16}\right)$, and a Genotype $x$ Day interaction $\left(F_{4,68}=6.60, p=0.00015\right)$. Simple contrasts revealed a significant decrease in distance traveled in KI males vs. B6J wild-type males on D3 ( $\left.{ }^{*} p=0.0016\right)$ and D4 ( $\left.{ }^{*} p=0.0001\right)$, but not on D5 ( $p=0.061)$.

Figure 5. Time course of distance traveled following acute methamphetamine administration on Day 3 in Gabra2 KI mice versus B6J wild-types. (A): Distance traveled on Day(D)3 across 5-min bins in KI vs. B6J wild-types. RM ANOVA revealed a main effect of Genotype $\left(F_{1,31}=5.723, p=0.023\right)$, Time $\left(F_{5,155}=96.60\right.$, $\left.p<2 \times 10^{-16}\right)$, and a Genotype $\times$ Time interaction $\left(F_{5,155}=4.27, p=0.0011\right)$. Simple contrasts revealed a significant decrease in distance traveled at $15 \mathrm{~min}(p=0.022), 20 \mathrm{~min}(p=0.016), 25 \mathrm{~min}(p=0.0078)$, and 30 $\min (p=0.0046)$. (B): Time course of distance traveled in females on D3 following acute methamphetamine administration. RM ANOVA indicated a main effect of Time $\left(F_{5,70}=31.74, p<2 \times 10^{-16}\right)$ but no effect of Genotype $\left(F_{1,14}<1\right)$ and no Genotype $x$ Time interaction $\left(F_{5,70}<1\right)$. (C): Time course of distance traveled in males on D3 following acute methamphetamine administration. RM ANOVA indicated a main effect of Genotype $\left(F_{1,17}=8,32, p=0.01\right)$, Time $\left(F_{5,85}=78.78, p<2 \times 10^{-16}\right)$, and a Genotype $\times$ Time interaction $\left(F_{5,85}=\right.$ $\left.6.53, p=3.5 \times 10^{-5}\right)$. Simple contrasts revealed a significant decrease in $\mathrm{KI}$ males vs. B6J wild-type males at $15 \min \left({ }^{*} p=0.0027\right), 20 \min \left({ }^{*} p=0.0017\right), 25 \min \left({ }^{*} p=0.0021\right)$, and $30 \min \left({ }^{*} p=0.0034\right)$.

Supplementary Figure 1. Power analysis for Day 3 distance traveled in B6J x B6NJ-F2 mice. Power versus effect size (\% variance explained) for an additive QTL model (no covariates) and a sample size of 184 F2 mice. $0.2,0.4,0.6$, and 0.8 power is achieved with an observed effect size of $3.86 \%, 5.65 \%, 7.41 \%$, and $9.65 \%$ variance explained, respectively.

Supplementary Figure 2. Correlation of Gabra2 expression in female versus male mice from various BXD-RI substrains with or without the Gabra2 intronic indel. Plotted number indicate the BXD-RI strain. BXD-RI strains with the mutant Gabra2 allele include 40,44, 60, 83, and 89. $X$ and $Y$-axes indicate the dataset from GeneNetwork. The hypothalamus was selected for this analysis because it had both females and males contained within the dataset. 


\section{FIGURE 1}

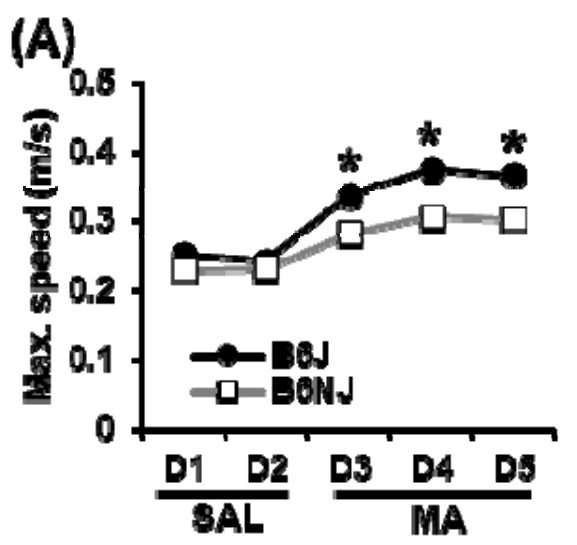

(D)



(B) FEMALES

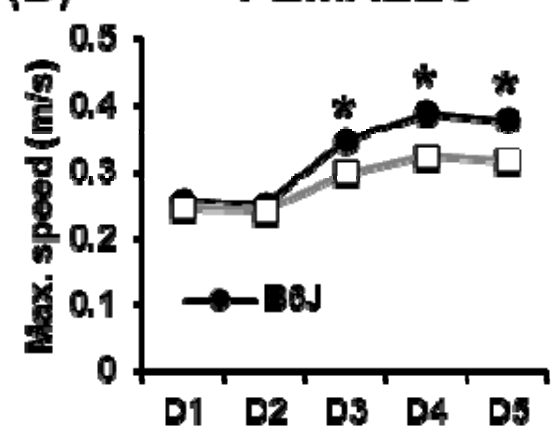

(E) FEMALES

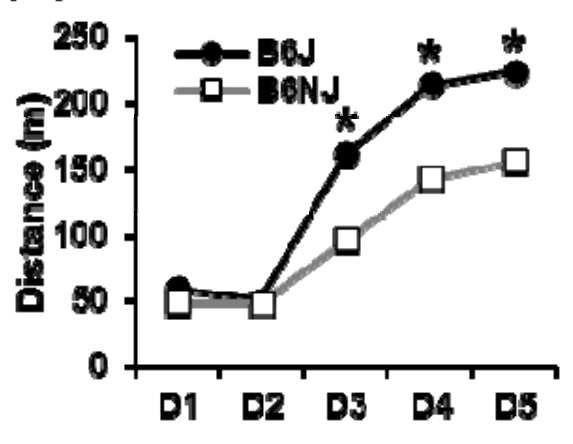

(C)



(F)

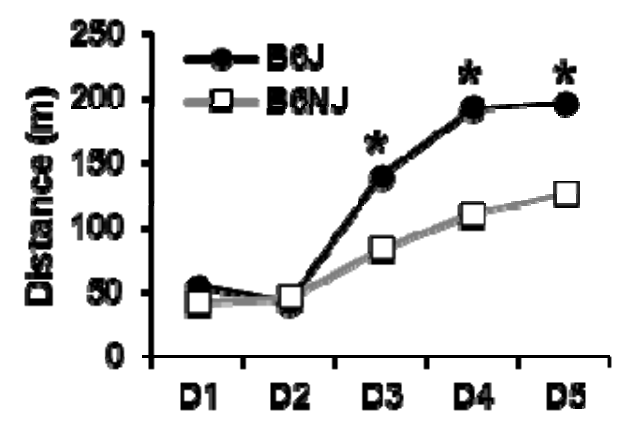


bioRxiv preprint doi: https://doi.org/10.1101/2021.06.29.450337; this version posted June 30, 2021. The copyright holder for this preprint (which was not certified by peer review) is the author/funder, who has granted bioRxiv a license to display the preprint in perpetuity. It is made available under aCC-BY-NC-ND 4.0 International license.

\section{FIGURE 2}

(A)

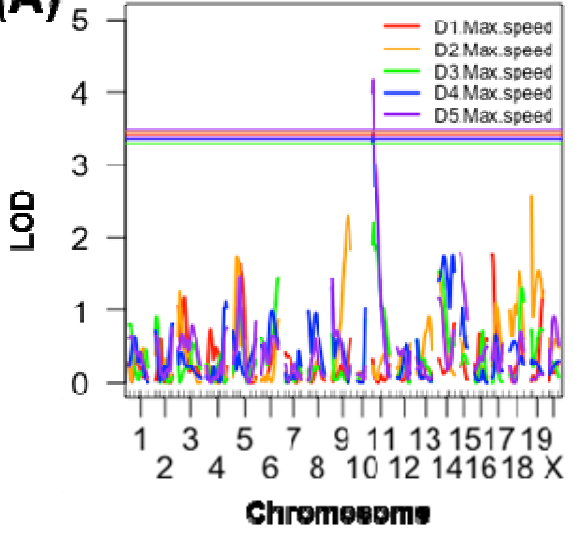

(B)

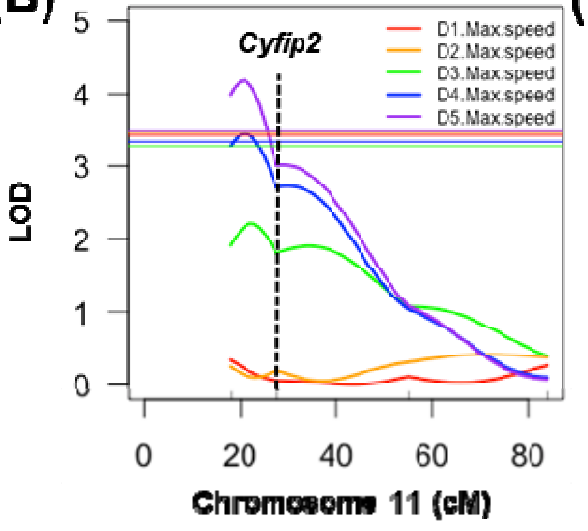

(C)

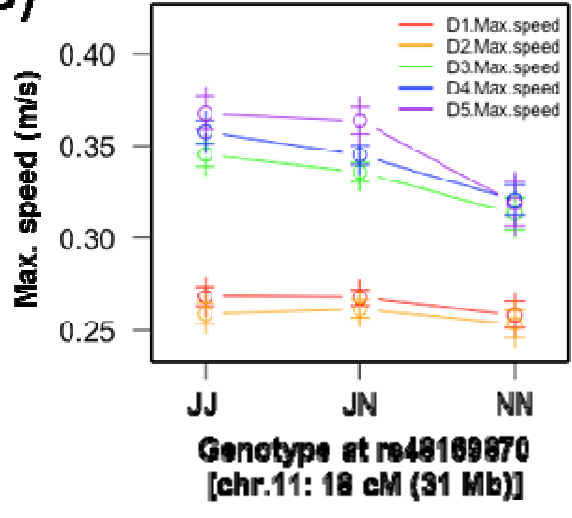




\section{FIGURE 3}

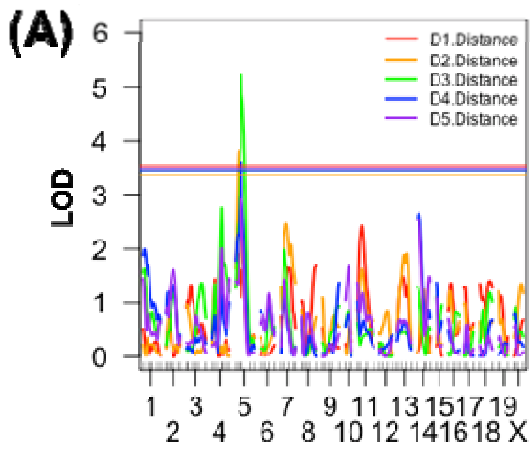

Chremoseme
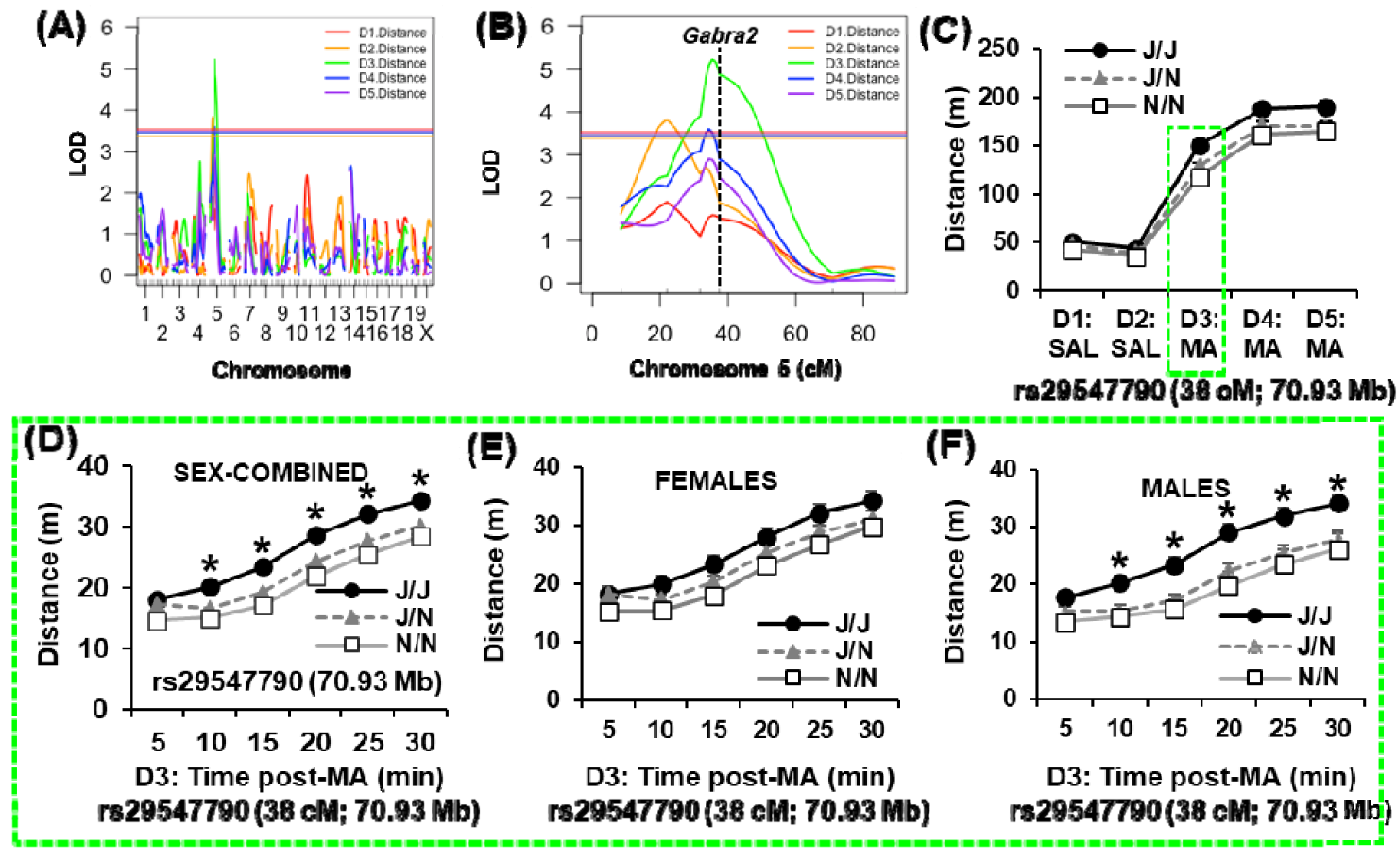
FIGURE 4

(A) Chr. 5: 71,014,638 bp (mm10) (B)
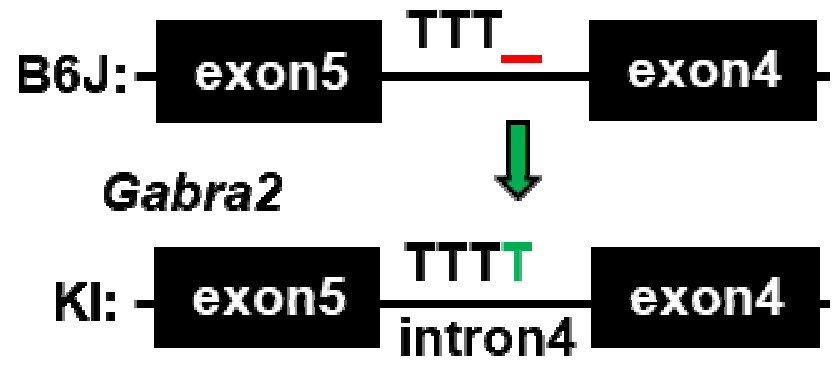

(C)

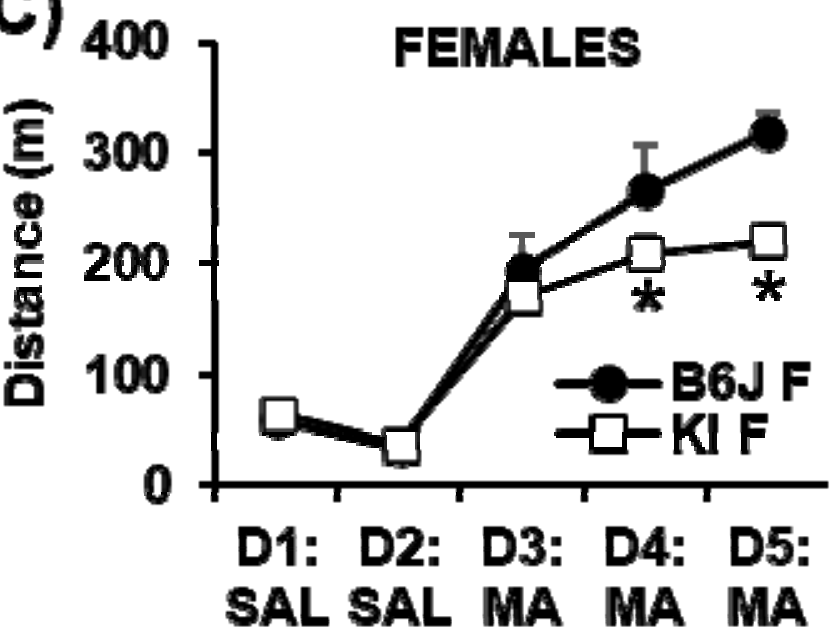

(D) 400

D1: D2: D3: D4: D5:

SAL SAL MA MA MA

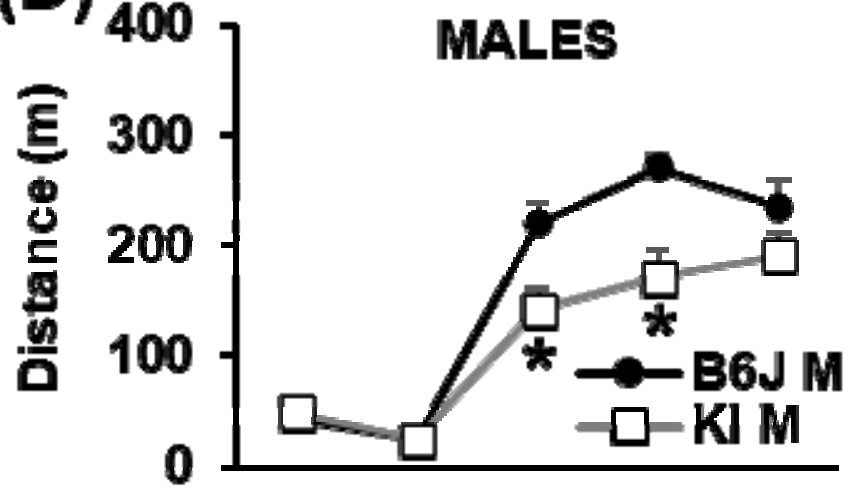

D1: D2: D3: D4: D5: SAL SAL MA MA MA 


\section{FIGURE 5}

bioRxiv preprint doi: https://doi.org/10.1101/2021.06.29.450337; this version posted June 30, 2021. The copyright holder for this preprint (which was not certified by peer review) is the author/funder, who has granted bioRxiv a license to display the preprint in perpetuity. It is made available under aCC-BY-NC-ND 4.0 International license.

\section{SUPPLEMENTARY FIGURE 1}

(A)

Day 3 Dlstance
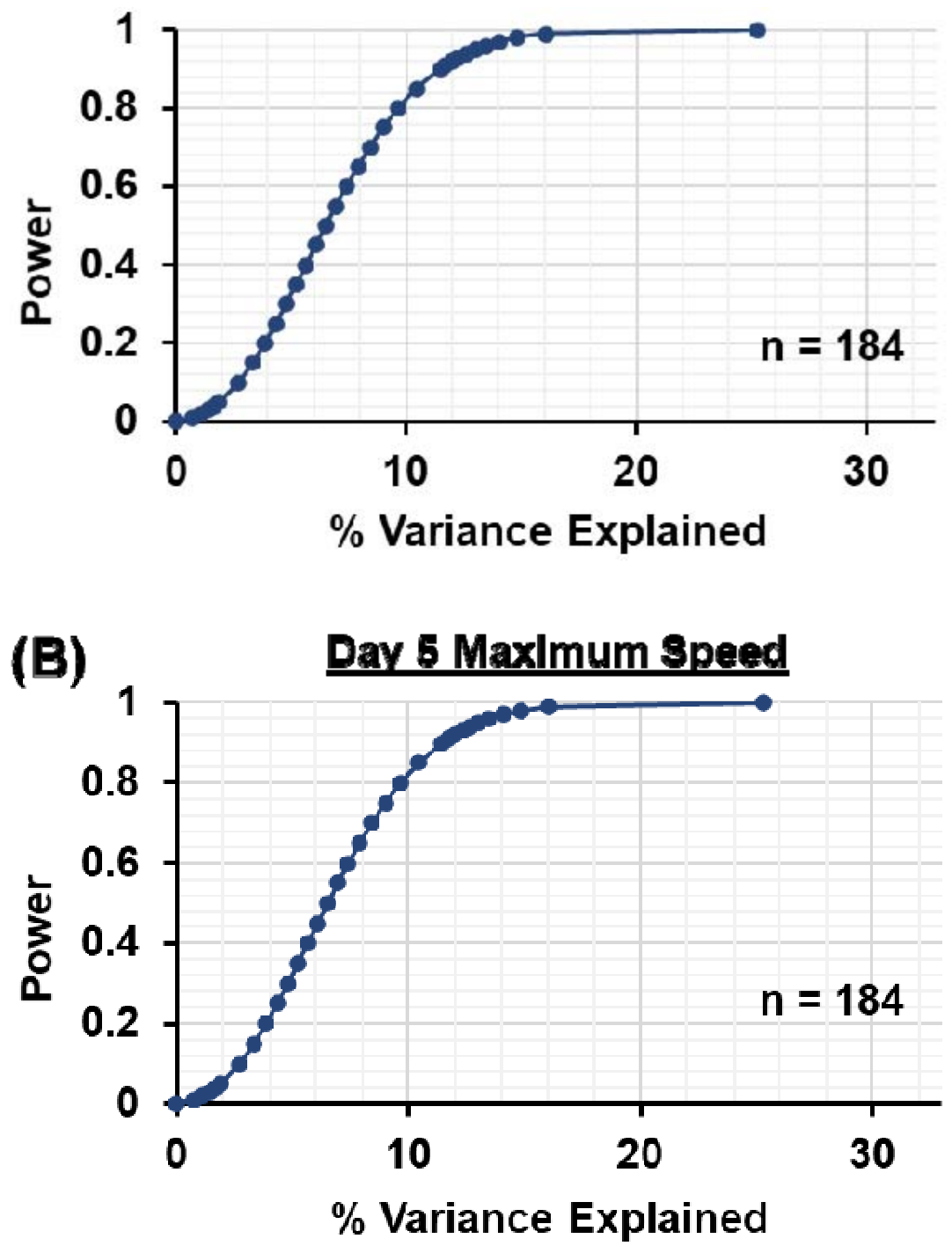
bioRxiv preprint doi: https://doi.org/10.1101/2021.06.29.450337; this version posted June 30, 2021. The copyright holder for this preprint (which was not certified by peer review) is the author/funder, who has granted bioRxiv a license to display the preprint in perpetuity. It is made available under aCC-BY-NC-ND 4.0 International license.

\section{SUPPLEMENTARY FIGURE 2}

\section{Pearson Correlation}

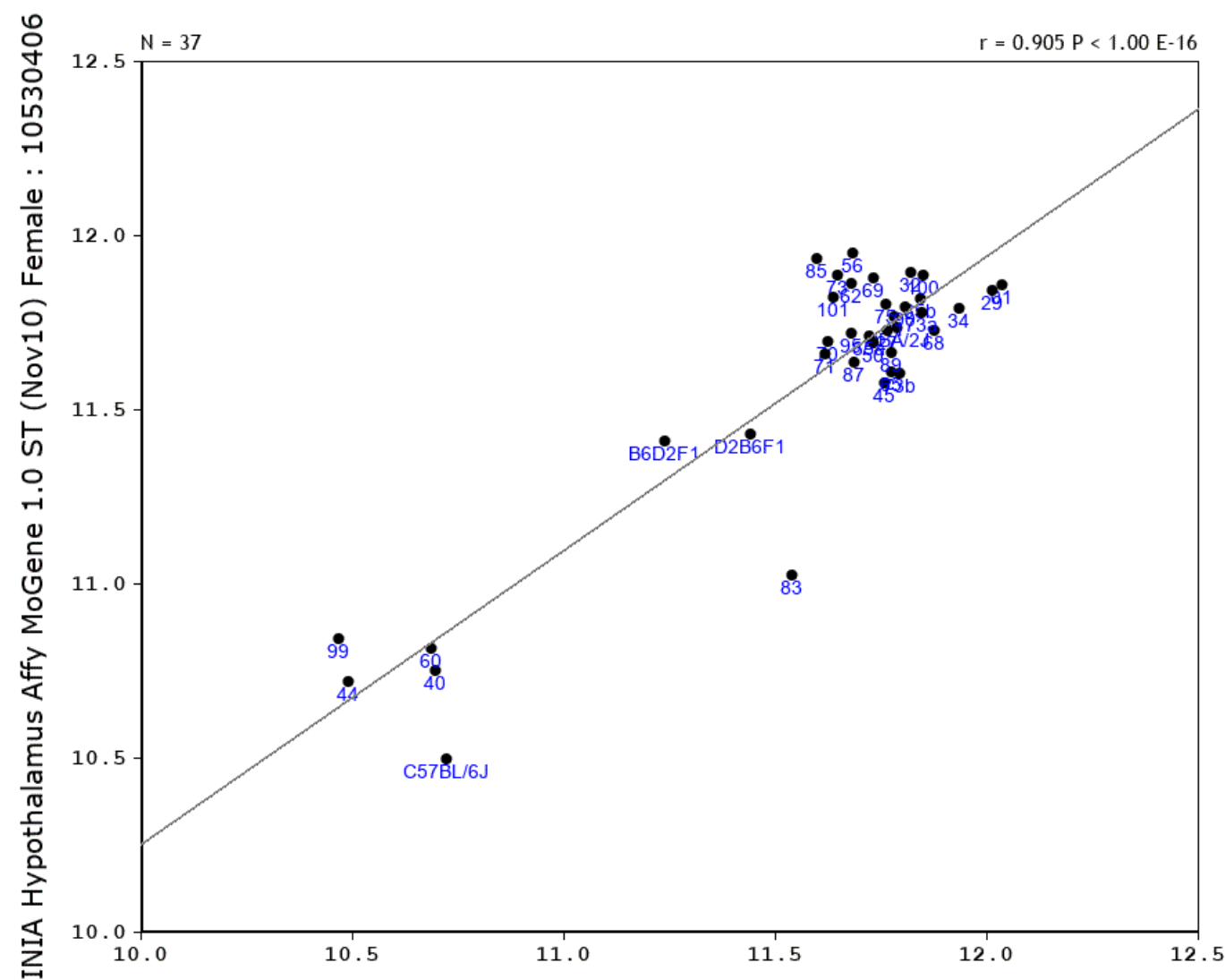

INIA Hypothalamus Affy MoGene 1.0 ST (Nov10) Male : 10530406 